\title{
Self-reactive B cells in the GALT are actively curtailed to prevent gut inflammation
}

\author{
Ashima Shukla, Cindi Chen, Julia Jellusova, Charlotte R. Leung, Elaine Kao, Numana Bhat, \\ Wai W. Lin, John R. Apgar, and Robert C. Rickert \\ Tumor Microenvironment and Cancer Immunology Program, Sanford Burnham Prebys Medical Discovery Institute, La Jolla, \\ California, USA
}

\begin{abstract}
Immune homeostasis in the gut-associated lymphoid tissues (GALT) is critical to prevent the development of inadvertent pathologies. B cells, as the producers of antibodies and cytokines, play an important role in maintaining the GALT homeostasis. However, the mechanism by which B cells specifically direct their responses toward non-self-antigens and become ignorant to self-antigens in the GALT is not known. Therefore, we developed what we believe to be a novel mouse model by expressing duck egg lysozyme (DEL) in gut epithelial cells in presence of HEL-reactive B cells. Notably, we observed a transient activation and rapid deletion of self-reactive B cells in Peyer's patches and mesenteric lymph nodes upon self-antigen exposure. The survival of self-reactive $B$ cells upon exposure to their self-antigen was partially rescued by blocking receptor editing but could be completely rescued by stronger survival signal, such as ectopic expression of BCL2. Importantly, rescuing the self-reactive $B$ cells promoted production of autoantibodies and gut inflammation. Mechanistically, we identify a specific activation of TGF- $\beta$ signaling in self-reactive B cells in the gut and a critical role of this pathway in maintaining peripheral tolerance. Collectively, our studies describe functional consequences and the fate of self-reactive B cells in CALT and provide potentially novel mechanistic insights governing self-tolerance of $B$ cells in the gut.
\end{abstract}

Authorship note: AS and CC contributed equally to this work.

Conflict of interest: The authors have declared that no conflict of interest exists.

Copyright: (c) 2019, American Society for Clinical Investigation.

Submitted: May 26, 2019

Accepted: July 11, 2019

Published: August 22, 2019

Reference information: JCI Insight. 2019;4(16):e130621.

https://doi.org/10.1172/jci.

insight.130621.

\section{Introduction}

The mammalian intestine is a complex environment that is continuously exposed to vast variety of antigens from commensal and pathogenic microbes as well as dietary factors (1-3). These antigens pose a unique challenge for the innate and adaptive immune system to discriminate between harmful versus innocuous antigens to restrain the spread of pathogenic microbes, while also avoiding aberrant inflammatory encounters $(4,5)$. Immune cells are positioned in the subepithelial layers where they constantly surveil for invading harmful pathogens. The immune system is an integral part of the gut tissue that is required for maintaining its homeostasis. The protective mucus layers, along with the secreted Igs, particularly IgA, represent critical checkpoints to prevent the entry and spread of pathogenic microbes (6-9). However, under certain pathological conditions, the unrestrained activation of immune responses due to a breach in the mucosal barrier leads to several autoimmune pathologies and perturbation of normal gut homeostasis $(2,10)$.

$\mathrm{B}$ cells are an intricate part gut immunity and also play a pivotal role in the maintenance of intestinal tissue. In the event of a breach in the epithelial barrier, B cells can respond to gut pathogens to prevent dissemination and ultimately resolve infection (11-14). B cells perform these functions by producing Igs as well as several immune modulatory cytokines (12-15). The Igs secreted by plasma cells are captured by poly-Ig receptors on the basolateral surface of the epithelia to mediate endocytosis of Ig complexes that can be cleaved and transported into the apical lumen via transcytosis where they serve to neutralize the foreign microbes. The Ig-antigen complexes also function to deliver antigens into the subepithelia for presentation to other immune cell subsets (7). Moreover, B cells in the gut are potent producers of immunomodulatory cytokines, such as IL-10, that have pleiotropic effects (16). These immunomodulatory cytokines are important for maintaining the immune homeostasis in the gut-associated lymphoid tissues (GALT), blunting excessive inflammatory responses, and regulating the balance between commensal and pathogenic microbes (14-17). Although, B cells are known to be important for maintaining gut homeostasis, the regulation of B cell responses in the gut is incompletely understood. 
B cell tolerance mechanisms, which include clonal deletion, receptor editing, and anergy, have been well investigated with regard to selection of newly formed B cells in bone marrow $(18,19)$. However, the tolerance mechanisms that limit self-reactivity to self-antigens expressed in peripheral tissues is less clear. We have previously shown that, in the context of an autoantigen expressed on follicular dendritic cells in the spleen, self-reactive B cells are rapidly eliminated at the transitional B cell developmental stage to limit self-reactivity (20). Whether similar mechanisms operate in much more convoluted peripheral tissue, such as the GALT, is not well studied. In GALT, discrimination of antigens from pathogenic bacteria, beneficial bacteria, food, and self-antigen by B cells is vital. Furthermore, in anatomical sites, such as Peyer's patches (PPs) and isolated lymphoid follicles, B cells are eliciting an immune response toward pathogenic antigens. The high degree of immune cell activation makes gut predispose to autoimmunity. How B cells make this distinction between self versus non-self at this site is not known. Interestingly, B cells have been shown to express RAG proteins and undergo Ig rearrangements in the lamina propria but not the PPs during neonatal development in the mouse, an event that coincides with establishment of the microbiota (21). These observations suggest that B cell tolerance appears to occur in the gut, where B cells may undergo secondary rearrangements to execute receptor editing and evade reactivity to putative self-antigens. Besides, the level of autoantibodies is often elevated in patients with inflamed gut, and it is unclear of whether self-reactive $\mathrm{B}$ cells initiate the disease or they get recruited at the site upon tissue destruction. Therefore, we wanted to investigate if specific mechanisms exist to render B cells tolerant to self-antigen in the gut.

In our studies, we developed what we believe to be a novel mouse model to study B cell tolerance against the duck egg lysozyme (DEL) as a neo-self-antigen expressed on gut epithelial cells. Strikingly, we observed that the self-reactive B cells are transiently activated in response to self-antigen before being rapidly eliminated in the PPs and the draining mesenteric lymph nodes (mLNs). The elimination of self-reactive $\mathrm{B}$ cells could be rescued by blocking receptor editing or by strong survival signaling, such as an ectopic overexpression of BCL2, but not by cell-extrinsic survival signals, such as excessive BAFF. Notably, the rescue of self-reactive B cell survival by expression of BCL2 lead to the production of autoantibodies to HEL, which ultimately progressed to the inflammation in gut and autoantibody production. Transcriptomic analysis revealed specific activation of the TGF- $\beta$ signaling pathway in self-reactive B cells in the GALT, and inhibition of this pathway altered the fate of self-reactive B cells in the gut and rescued their survival. To our knowledge, this is the first model to study B cell tolerance in the GALT. In our model, mature self-reactive B cells get eliminated in the gut; however, the pool in tissues such as spleen remains unaltered. Our work defines how B cell tolerance mechanisms operate in the gut to limit self-reactivity and provide mechanistic insights into the molecular pathways regulating these events.

\section{Results}

Self-reactive B cells are eliminated upon antigen encounter in the gut. B cells in gut GALT are constantly exposed to a range of potential antigens; however, the B cell immune responses are kept in check by the induction of peripheral tolerance at steady state. How the peripheral tolerance in gut is induced and maintained remains poorly understood. To gain insights into this process, we generated a model by crossing transgenic mice expressing membrane-bound DEL (mDEL) with mice carrying Villin-Cre to obtain Villin ${ }^{\text {cre }} \mathrm{mDEL} \mathrm{L}^{\text {loxp }}$ mice. In these mice, upon Cre-mediated recombination, $\mathrm{mDEL}$ was expressed uniformly and exclusively throughout the gut epithelial cells, including M cells. DEL displayed a much lower affinity ( 3500 -fold, $1.3 \times 10^{7}$ per M) for the HEL-specific B cell receptors (BCR), which are often used as a model to study central and peripheral tolerance, compared with an extraordinarily high affinity exhibited by HEL $\left(4.5 \times 10^{10}\right.$ per M), which perhaps makes DEL a more physiological model to study tolerance $(22,23)$. To study the induction of B cell tolerance, we further bred the Villin ${ }^{\text {cre }} \mathrm{mDEL}^{\text {loxp }}$ mice with the $\mathrm{SW}_{\mathrm{HEL}}$ knockin mice that generate self-reactive HEL-specific B cells (Figure 1A). B cells from $\mathrm{SW}_{\mathrm{HEL}}$ mice expressed the same rearranged BCR allele as those in the MD4 HEL-transgenic mice, with the exception that the rearranged HEL-specific allele in $\mathrm{SW}_{\mathrm{HEL}}$ mice was targeted into the $\operatorname{IgH}$ locus. $10 \%-25 \%$ of peripheral $\mathrm{B}$ cells in adult $\mathrm{SW}_{\mathrm{HEL}}$ mice display specificity to HEL and undergo receptor editing, normal isotype switching, as well as somatic hypermutation (24).

We first examined whether the expression of DEL in gut epithelia indirectly affects the gut microbiome. Fecal samples were collected from mice with several different genotypes, including those from the Villin $^{\text {cret }} \mathrm{mDEL}^{\text {loxp}} \mathrm{SW}_{\mathrm{HEL}}$ mice and Villin ${ }^{\text {cre+ }} \mathrm{SW}_{\mathrm{HEL}}$ mice not expressing DEL (Supplemental Figure $1 \mathrm{~A}$; supplemental material available online with this article; https://doi.org/10.1172/jci.insight.130621DS1). 
Additionally, fecal samples were also obtained from wild-type mice following administration of HEL via oral gavage at multiple time points. Bacterial genomic DNA was purified from different samples and deep sequenced for the V4 region of the 16S rRNA gene to measure the diversity of bacterial phyla. The microbial diversity was mostly unaffected by the presence of DEL as a membrane fusion protein or by acute oral administration of HEL (Supplemental Figure 1B). This clearly indicated that perturbation of the gut microbiome is not a cell-extrinsic obfuscating factor of B cell tolerance to DEL as a specific autoantigen in our model.

Next, to determine the effect of gut-associated antigen (mDEL) on the fate of self-reactive B cells, 8- to 10-week-old Villin ${ }^{\text {cret }} \mathrm{mDEL}{ }^{\text {loxp}} S W_{\mathrm{HEL}}$ mice and Villin ${ }^{\text {cre }} \mathrm{SW}_{\mathrm{HEL}}$ mice, which do not express DEL, were analyzed. HEL-specific B cells from spleens, peripheral lymph nodes (pLNs), mLNs, and PPs were examined. Notably, we observed a striking decrease in HEL-specific cells in PPs ( 10 fold $)$ and mLNs and pLNs ( $\sim 6$ - to $\sim 7$-fold) in Villin ${ }^{\text {cret }} \mathrm{mDEL}{ }^{\text {loxp }} \mathrm{SW}_{\mathrm{HEL}}$ mice when compared with Villin ${ }^{\text {cre+ }} \mathrm{SW}_{\mathrm{HEL}}$ mice. Importantly, no differences in overall frequencies of B cells were observed Figure 1, B and C. These data clearly show a prominent reduction of HEL-specific B cells upon encounter with a gut-associated "self-antigen."

To further elucidate whether self-reactive B cells are acutely eliminated upon self-antigen exposure at GALT, adoptive transfers of splenic B cells and bone marrow reconstitution from $\mathrm{SW}_{\mathrm{HEL}}$ mice into Villin ${ }^{\text {cret }}$ and Villin ${ }^{\text {cret }} \mathrm{mDEL}^{\text {loxp }}$ mice were performed. Splenic B cells were isolated from SW $\mathrm{HEL}_{\text {mice }}$ and were labeled with efluor670 dye and intravenously transferred into Villin ${ }^{\text {cret }}$ and Villin ${ }^{\text {cret }} \mathrm{mDEL}^{\text {loxp }}$ mice. Two recipient mice from each group were sacrificed on day 1, 3, and 5 after transfer, followed by the analysis of spleens, pLNs, mLNs, and PPs. The decrease in frequencies of HEL-specific B cells in PPs and pLNs was observed as early as 24 hours after transfer, while the frequencies of HEL-specific B cells in spleens and mLNs appeared comparable (Supplemental Figure 2). We then analyzed the mice reconstituted with bone marrow cells from $\mathrm{SW}_{\mathrm{HEL}}$ mice (referred to herein as RVillin ${ }^{\text {cre+ }}$ and RVillin ${ }^{\text {cre+ }} \mathrm{mDEL}^{\text {loxp }}$ mice). At 8 weeks after reconstitution, HEL-specific $\mathrm{B}$ cells developed normally in RVillin ${ }^{\mathrm{Cre}} \times \mathrm{mDEL}^{\text {loxP }}$ mice and constituted similar frequencies among total B cells when compared with RVillin ${ }^{\text {Cre }}$ controls in the spleen (Figure 1, D and E). However, similar to Villin ${ }^{\text {cret }} \mathrm{mDEL}^{\text {loxp}} \mathrm{SW}_{\mathrm{HEL}}$ mice, a strong reduction in HEL-specific $\mathrm{B}$ cells in the ( 2-fold) PPs and ( 1.5 fold) pLNs of RVillin ${ }^{\text {Cre }} \times \mathrm{mDEL}^{\text {loxP }}$ mice was observed when compared with RVillin ${ }^{\mathrm{Cre}}$ mice. Collectively, these results suggest that HEL-specific self-reactive B cells are specifically eliminated upon encountering their self-antigen in GALT.

HEL-specific self-reactive $B$ cells show an increased turnover rate in PPS. We observed a strong reduction in HEL-specific self-reactive B cells in the GALT in the presence of a gut-associated self-antigen. This prompted us to further examine the turnover of HEL-specific cells at these sites. BCR stimulation by their cognate antigens is known to induce cell proliferation. However, whether BCR stimulation in the context of a self-antigen in the gut would induce proliferation of self-reactive B cells is not clear. To test this, we studied the cell kinetics and trafficking of HEL-specific B cells by continuously feeding BrdU-containing water to Villin $^{\text {cre }} m \mathrm{mDEL}^{\text {loxp}} \mathrm{SW}_{\mathrm{HEL}}$ and Villin ${ }^{\mathrm{Cre}+} \mathrm{SW}_{\mathrm{HEL}}$ mice as well as RVillin ${ }^{\mathrm{Cre}} \times \mathrm{mDEL}^{\text {loxP }}$ and RVillin ${ }^{\mathrm{Cre}}$ mice for 8 weeks. This approach labeled all the proliferating cells with BrdU and, therefore, allowed us to determine the rate of replenishment of tissue-resident cellular pools. We observed an almost 100 percent labeling of bone marrow cells with BrdU, and we traced the relative frequency of HEL-specific BrdU' cells in PPs, pLNs, mLNs, and spleens as a snapshot to determine the turnover of HEL-specific B cells at these different sites. Notably, approximately $50 \%$ of HEL-specific B cells in the PPs of Villin ${ }^{\text {cret }} \mathrm{mDEL}^{\text {loxp}} \mathrm{SW}_{\mathrm{HEL}}$ mice were labeled with BrdU compared with $25 \%$ in Villin ${ }^{\mathrm{Cre}+} \mathrm{SW}_{\mathrm{HEL}}$ mice (Figure $2 \mathrm{~A}$ ). A much weaker trend for BrdU ${ }^{+} \mathrm{HEL}$-specific $B$ cells was also seen in $\mathrm{pLNs}$, mLNs, and spleens of Villin ${ }^{\text {cret }} \mathrm{mDEL}^{\text {loxp }} \mathrm{SW}_{\mathrm{HEL}}$ mice. Similar results were observed in RVillin ${ }^{\mathrm{Cre}} \times \mathrm{mDEL}^{\text {loxP }}$ and RVillin ${ }^{\mathrm{Cre}}$ mice (Figure $2 \mathrm{~B}$ ). The replenishment of newly formed cells was not observed in non-HEL-specific cells (Figure 2C). These data could be reconciled in two possible ways: either HEL-specific B cells transiently proliferate upon encountering present cognate antigen in GALT or they are constantly replenished by BrdU-labeled cells from the bone marrow. To test the first scenario, we isolated and labeled splenic B cells from $\mathrm{SW}_{\mathrm{HEL}}$ mice with efluoro670 dye to track their proliferation. The labeled B cells were intravenously transferred into Villin ${ }^{\text {cre+ }} \mathrm{mDEL}^{\text {loxp }}$ and Villin ${ }^{\mathrm{Cre}+}$ mice. However, the proliferation of transferred SW ${ }_{\mathrm{HEL}}$ cells in PPs between Villin ${ }^{\text {cret }} \mathrm{mDEL}^{\text {loxp }}$ and Villin ${ }^{\mathrm{Cre}+}$ mice appeared comparable at day 1, 3, and 5 after transfer. This suggests that the increased frequency of BrdU ${ }^{+}$cells in Villin ${ }^{\text {cre }} \mathrm{mDEL}^{\text {loxp }}$ mice did not occur as a consequence of transient antigen-driven cellular proliferation (Figure 2D) but most likely resulted from an intensive replenishment of HEL-specific cells in PPs by BrdU-labeled B cells from bone marrow.

HEL-specific self-reactive $B$ cells are activated upon antigen encounter in GALT. HEL-specific B cells showed comparable proliferative responses in the presence (Villin ${ }^{\text {cret }} \mathrm{mDEL}^{\text {loxp }}$ ) or absence $\left(V_{11 l i n}^{\mathrm{Cre}+}\right)$ 
A

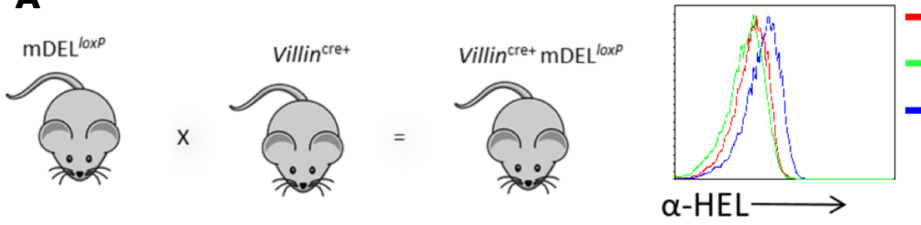

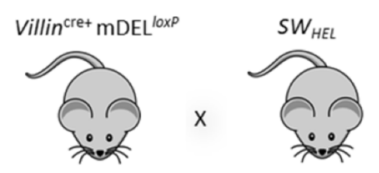

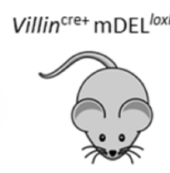

$$
\begin{aligned}
& \text { - Villin }{ }^{\text {cre+ }} \\
& \text { - } \mathrm{mDEL}^{\text {loxp }} \\
& \text { - Villin }{ }^{\text {cre+ }}{ }^{\mathrm{mDEL}}{ }^{\text {loxp }}
\end{aligned}
$$

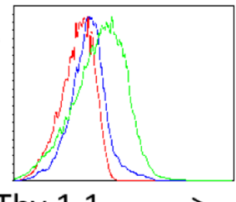

D

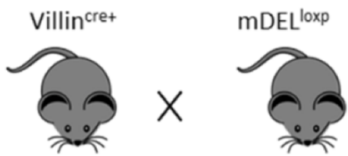

Thy $1.1 \longrightarrow$

$\mathrm{mDEL}$ is conditionally expressed in the gut<smiles>C=[V]</smiles>

Lethally irradiate Villin ${ }^{\text {cre }}+m D E L^{\text {loxp }}$

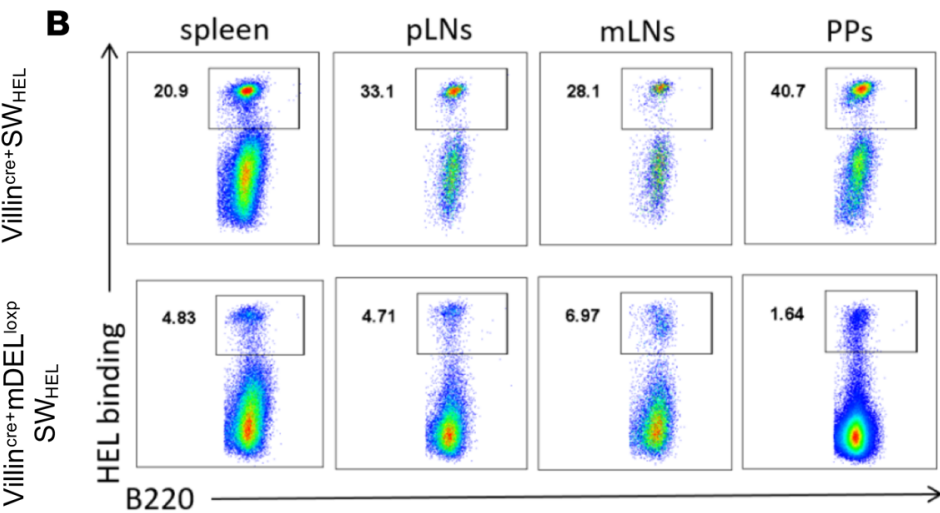

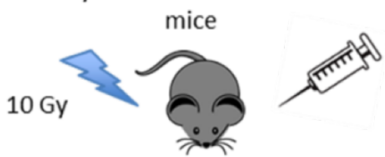

Reconstitute with $\mathrm{SW}_{\mathrm{HE}}$ bone

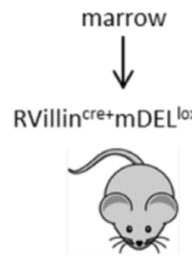

Mice with autoreactive B cells (SWHEL B cells) to gut associated pseudo self-Ag (mDEL)

\section{c}
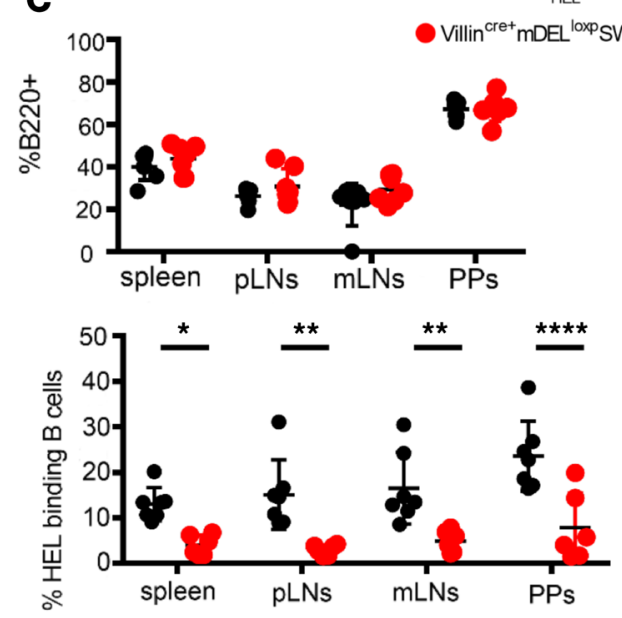

E
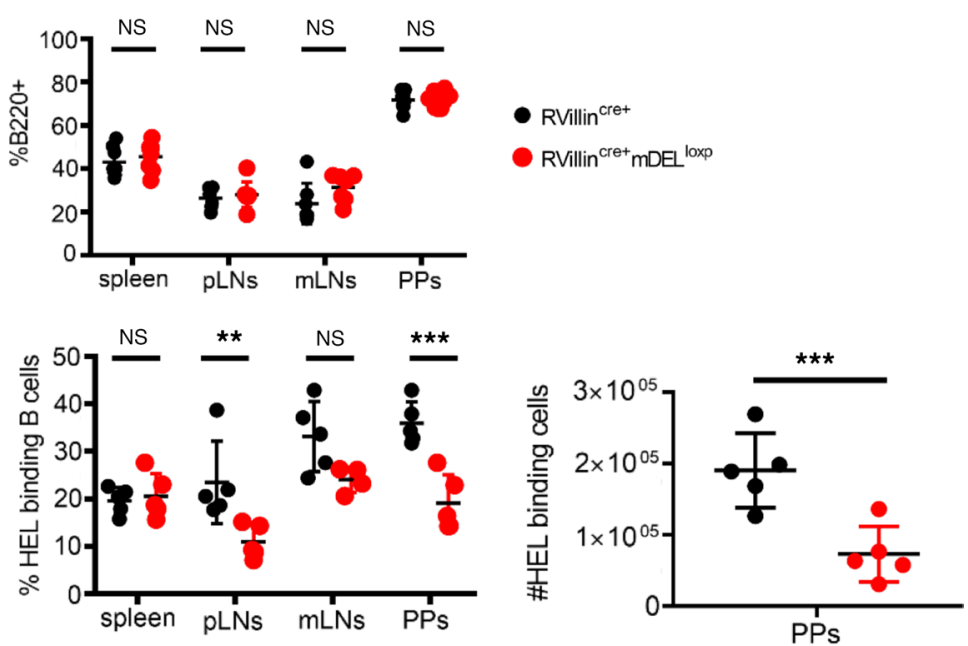

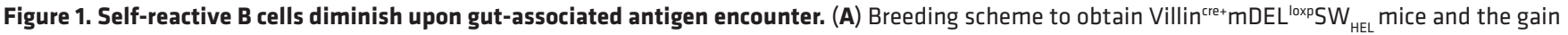
of DEL expression and loss of Thy 1.1 upon Villin ${ }^{\text {cre }}$ recombination, as measured by flow cytometry. (B) HEL-specific cell population (gated on B220 $\mathrm{HEL}^{+}$) in spleens, $\mathrm{pLNs}, \mathrm{mLNs}$, and PPs of Villin ${ }^{\text {cre }} \mathrm{mDEL}^{\text {loxp }} \mathrm{SW}_{\mathrm{HEL}}$ and Villin ${ }^{\text {cre }+} \mathrm{SW}_{\text {HEL }}$ mice. (C) B cells frequencies (gated on live cells, B220 $\mathrm{O}^{+}$as analyzed by flow cytometry in spleens, pLNs, $\mathrm{mLNs}$, and PPs of Villin ${ }^{\text {cre+ }} \mathrm{mDEL}^{\text {loxp }} \mathrm{SW}_{\text {HEL }}$ and Villin ${ }^{\text {cre }}+\mathrm{SW}_{\text {HEL }}$ mice at the age of 6-8 weeks. Data were analyzed using 2-way

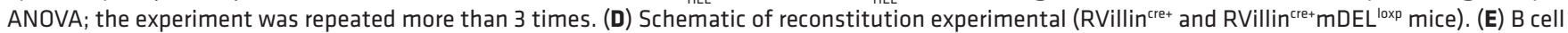
percentages in spleens, pLNs, mLNs, and PPs and HEL-specific cell percentages in spleens, pLNs, mLNs, and PPs and absolute numbers of HEL-specific $B$ cells in PPs isolated from RVillin ${ }^{\text {cret }}$ and RVillin ${ }^{\text {cret }} \mathrm{mDEL}^{\text {loxp }}$ mice after 8 weeks after reconstitution. Data are representative of 3 mice per group; the experiment was repeated more than 3 times; and data were analyzed using 2-way ANOVA and grouped multiple $t$ test. ${ }^{* * * *} P<0.0001,{ }^{* *} P<0.005,{ }^{* * *}$ $P<0.001,{ }^{*} P<0.05$. 
A

- Villincre+SWHEL

- Villincre+mDELloxpSW $W_{\text {HEL }}$

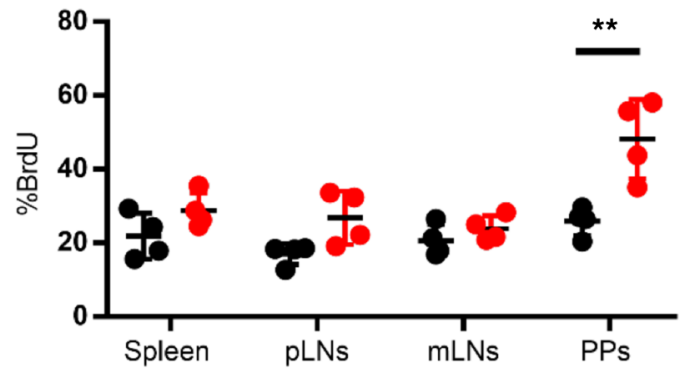

B

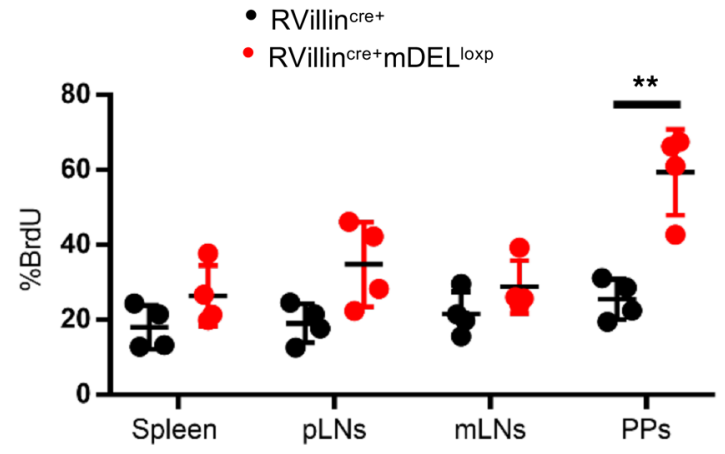

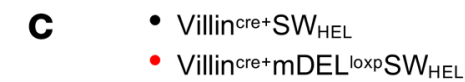
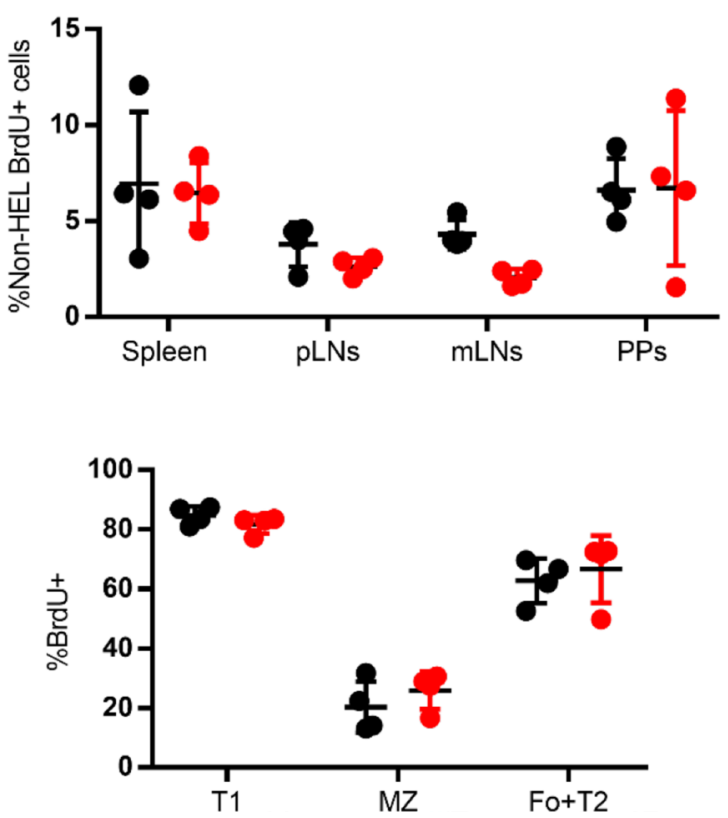

D Villincre+

:1:-1:-:.'

Villin ${ }^{\text {cre }}{ }^{m} \mathrm{mDE} L^{\operatorname{loxp}}$

$\mathrm{mLNs}$

PPs

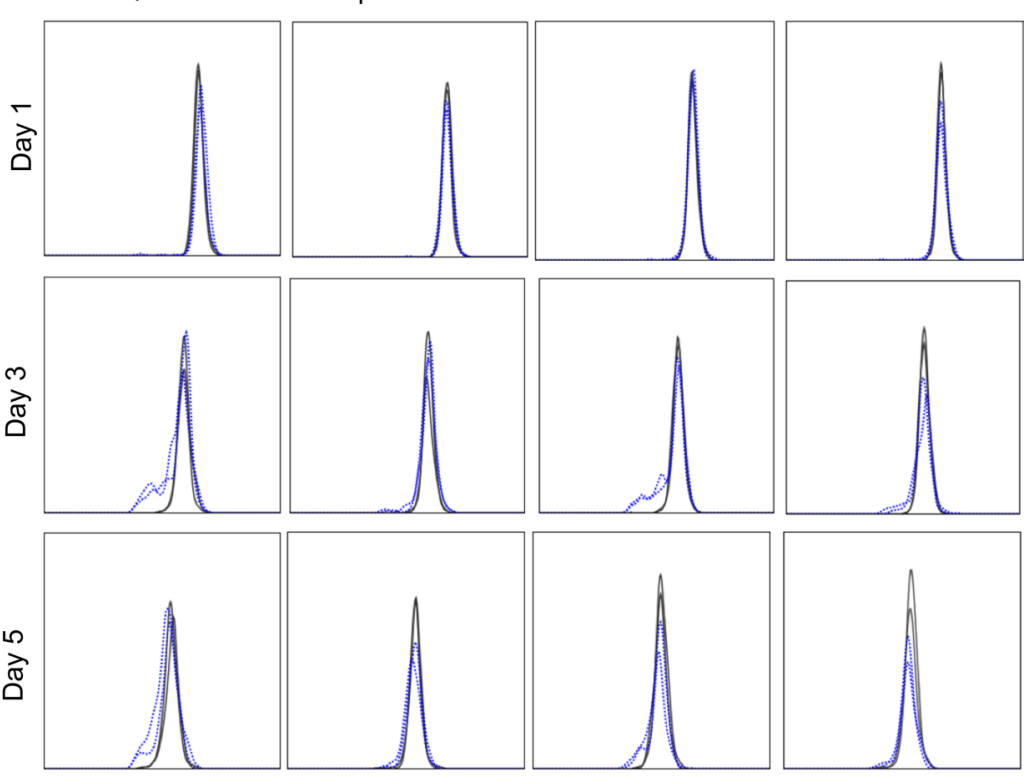

Figure 2. The pool of self-reactive B cells is renewed in gut by bone marrow. Mice were kept on BrDU-containing water for 8 weeks after reconstitution.

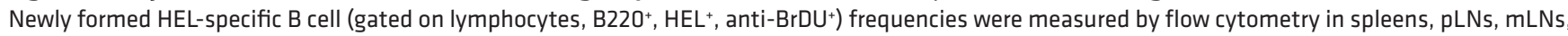

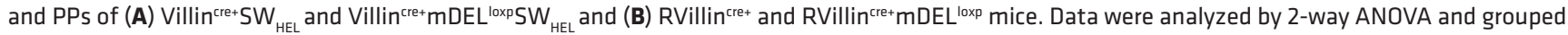
multiple $t$ test. (C) Frequencies of BrDU+ non-HEL-specific cells in spleens, pLNs, mLNs, and PPs and frequencies of BrDU+ $\mathrm{HEL}^{-s p e c i f i c ~ t r a n s i t i o n a l ~ s t a g e ~} 1$ B cells (T1), marginal zone B cells (MZ), follicular B cells (Fo), and transitional stage 2 B cells (T2) in spleens. (D) Histograms displaying the MFI of eFluor670 to determine proliferation of adoptively transferred HEL-specific B cells (gated on lymphocytes, single cells, eFluor670', B220 ${ }^{+}, \mathrm{HEL}^{+}$) in spleens, pLNs, $\mathrm{mLNs}$, and PPs into Villin ${ }^{\text {cre }+} m D E L^{\text {wt }}$ and Villin ${ }^{\text {cre }}+\mathrm{mDEL}^{\text {loxp }}$ mice. Data are representative of 2 mice per group sacrificed on 1,3 , and 5 days after transfer. Grouped statistical analysis was performed by multiple $t$ test. ${ }^{* *} P<0.005$.

of its cognate antigen. Therefore, we next analyzed whether HEL-specific B cells display features of cellular activation upon antigen encounter. BCR, upon binding to its antigen, is internalized, and, as a consequence, the cell surface levels of BCR are downregulated. We compared the cell surface levels of HEL-binding BCR of HEL-specific self-reactive B cells upon antigen encounter in RVillin ${ }^{\text {Cre }} \mathrm{mDEL}^{\text {loxP }}$ mice. An approximately 2- and 1.5-fold reduction in the MFI of surface Ig and HEL-specific BCR were observed in mLNs and PPs of RVillin ${ }^{\mathrm{Cre}} \mathrm{mDEL}{ }^{\text {loxP }}$ mice compared with HEL-specific B cells from RVillin ${ }^{\text {Cre }}$ mice (Figure 3, A, B, and E). Moreover, the levels of cell surface Ig and HEL-specific BCR were comparable at lymphoid tissues not expressing the antigen, such as pLNs and spleens. We also evaluated the expression of B cell activation markers, CD69 and CD86, on HEL-specific B cells in the 
RVillincre+ $\square$ RVillincre+mDEL Ioxp

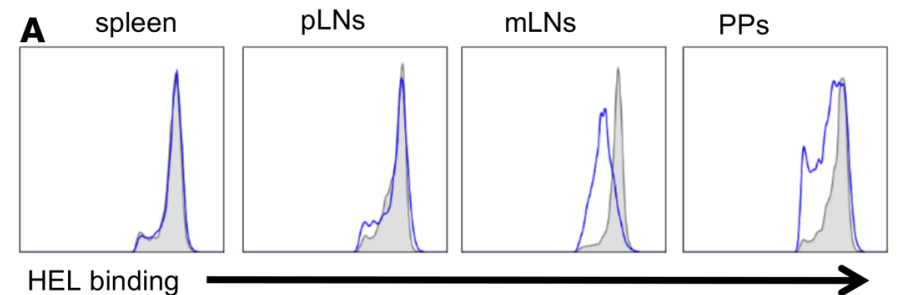

B
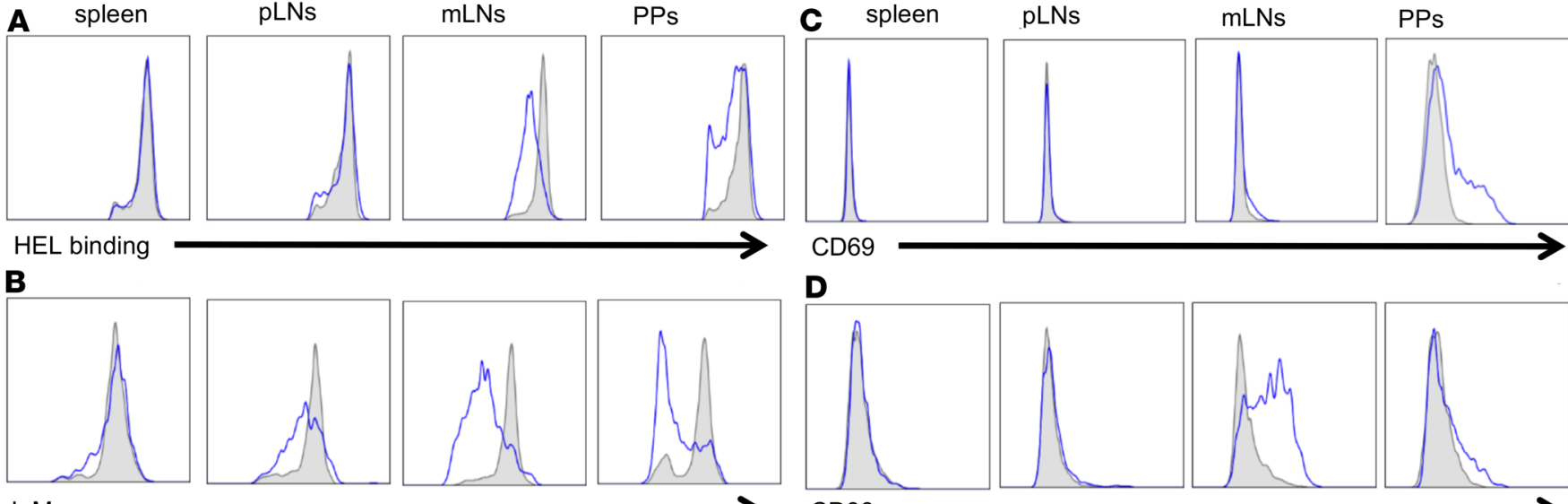

CD69

D
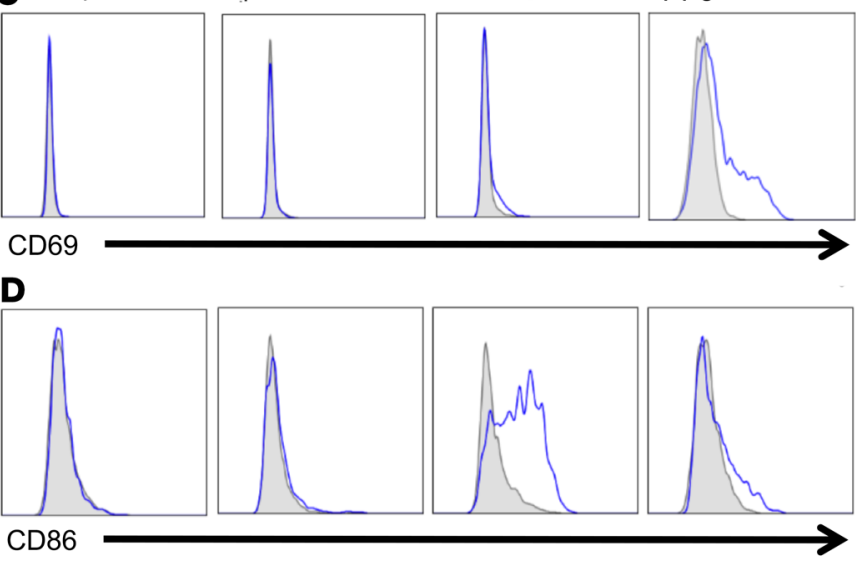

트
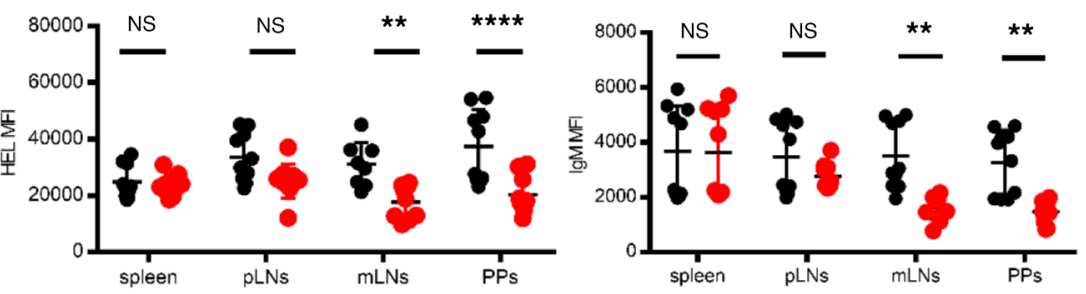

- RVillincre+

- RVillincre+mDEL loxp
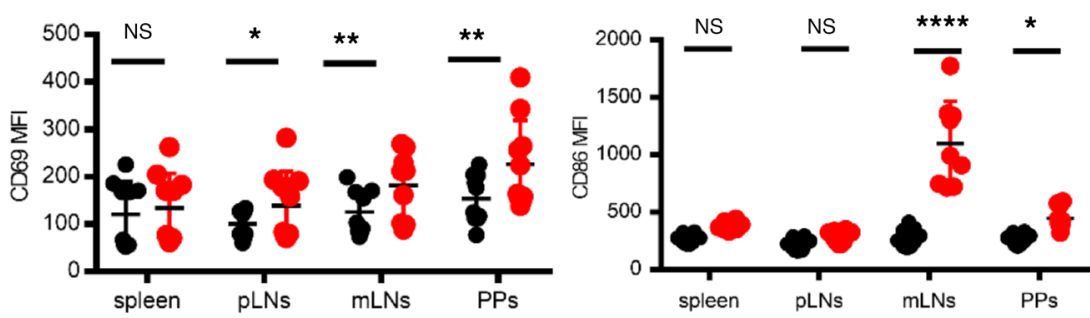

F

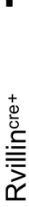

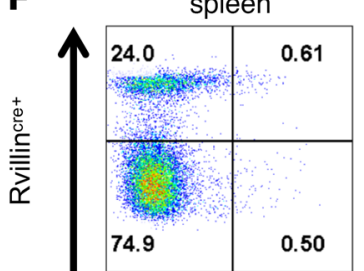

范
pLNs
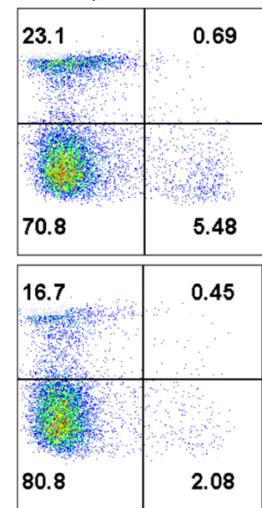
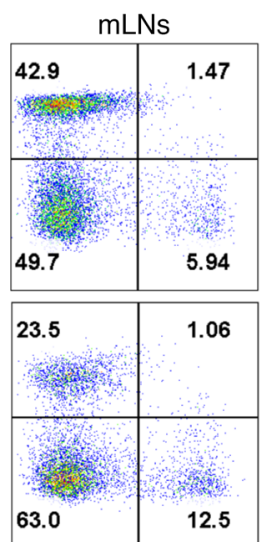
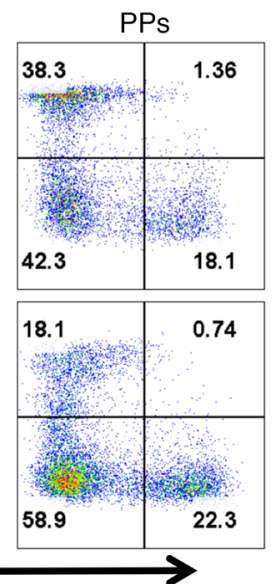

G

- RVillincre+

- RVillin ${ }^{\text {cre+ }}{ }^{2}$ DEL $L^{\text {loxp }}$

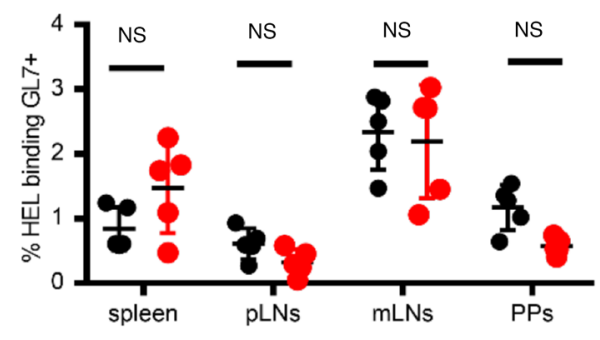

Figure 3. Self-reactive B cells are activated upon antigen encounter in gut. HEL-specific cells were isolated from spleens, pLNs, mLNs, and PPs of RVillin $^{\text {cret }}$ and RVillin ${ }^{\text {cret }}$ mDEL ${ }^{\text {loxp }}$ mice. BCR density, as measured by MFI of (A) HEL-binding histograms of HEL-specific cells, with (E) the MFI of HEL binding of HEL-specific cells, and(B) anti-IgM histograms of HEL-specific cells, with (E) the MFI of IgM of HEL-specific cells from 8 mice per group. Activation of HEL-specific cells was measured. (C) CD69 histograms of HEL binding, with (E) the MFI of CD69. (D) CD86 histograms of HEL binding, with (E) the MFI of CD86 in HEL-specific cells from 8 mice per group. (F) Gated on B220+, dot plots of HEL-specific cells (HEL+) and germinal center cells (GL7+) in spleens, pLNs, mLNs, and PPs. (G) GL7+HEL+ cells in spleens, $\mathrm{pLNs}, \mathrm{mLNs}$, and PPs of 5 mice per group. Grouped statistical analysis was performed by multiple $t$ test. ${ }^{* * *} P<0.0001,{ }^{* *} P<0.005,{ }^{* *} P<0.001,{ }^{*} P<0.05$. 
presence or absence of its antigen. We observed an increase in the levels of CD69 and CD86 in PPs and mLNs of RVillin ${ }^{\text {Cre }} \mathrm{mDEL}^{\text {loxP }}$ mice compared with RVillin ${ }^{\text {Cre }}$ mice (Figure 3, C and D). Interestingly, the upregulation of CD69, which is considered an early marker of cell activation, was much more pronounced on HEL-specific B cells in the PPs, while CD86, an activation marker with costimulatory functions, was significantly upregulated in mLNs. These data indicate that HEL-specific B cells, upon encountering the self-antigen at the gut epithelia, are transiently activated and a subset among these cells traffic to the mLN, where they undergo further activation. Even though the HEL-specific B cells underwent activation, they failed to enter the germinal center reaction, as indicated by the lack of germinal center B marker, GL7 (Figure 3, F and G). Together, these data show that HEL-specific B cells undergo activation upon antigen encounter in the GALT.

Self-reactive B cells undergo deletion and receptor editing in the GALT. Our results showed that HEL-specific B cells, upon binding to self-antigen in GALT, undergo cellular activation, and their numbers undergo reduction. This suggests that upon antigen encounter the majority of HEL-specific B cells in GALT are clonally deleted or are shunted toward a terminal differentiation pathway, leading to the generation of short-lived plasma cells. To address these scenarios, we first monitored the production of autoantibodies specific to HEL by using a flow-based assay developed in our laboratory (25). Serum and fecal extracts were collected from RVil$\operatorname{lin}^{\mathrm{Cre}+} \mathrm{mDEL}{ }^{\text {loxP }}$ and control RVillin ${ }^{\mathrm{Cre}+}$ mice, and then the antibody titers were measured. We did not observe any significant differences in the production of HEL-specific antibodies of IgM, IgG1, and IgA isotypes in the sera and fecal extracts (Supplemental Figure 3, A and B). These results demonstrate that HEL-specific B cells upon antigen encounter are not channeled toward a terminal plasma cell differentiation pathway.

We then investigated the possibility for clonal elimination of HEL-specific B cells upon encountering self-antigen in GALT. We analyzed several markers associated with cell death on HEL-specific cells from

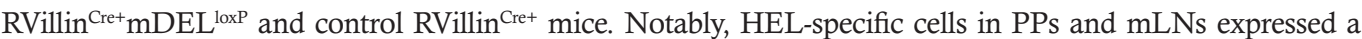
significant increase in the proapoptotic protein, BIM (Figure 4A), and annexin V (Supplemental Figure 3C). Histological examination of HEL-specific B cells in PPs of RVillin ${ }^{\mathrm{Cre}} \mathrm{mDEL}^{\text {loxP }}$ mice also showed higher BIM positivity (Figure 4B); however, the architecture of follicles was retained (Supplemental Figure 4F). These results indicate that self-reactive $\mathrm{B}$ cells undergo elimination upon encountering its antigen. To test whether the provision of an external survival signal would prevent the elimination of self-reactive B cells in GALT, we used a human CD68 promoter-driven BAFF-transgenic mouse line and crossed it to $\mathrm{SW}_{\mathrm{HEL}}$ mice $\left(\mathrm{SW}_{\mathrm{HEL}}\right.$ Baff) (26). BAFF belongs to the TNF superfamily of receptors and is a well-known survival factor for mature B cells in the periphery. The RVillin ${ }^{\mathrm{Cre}+} \mathrm{mDEL} \mathrm{L}^{\mathrm{loxP}}$ and control RVillin ${ }^{\mathrm{Cre}+}$ mice were then reconstituted by the bone marrow cells from $\mathrm{SW}_{\mathrm{HEL}}$ Baff mice $\left[\mathrm{RVillin}^{\mathrm{Cre}} \mathrm{mDEL}^{\operatorname{loxP}}(\right.$ Baff $\left.)\right]$ and $\left[\mathrm{RVillin}^{\mathrm{Cre}+}(\right.$ Baff)]. Rather surprisingly, even the overexpression of BAFF could not rescue the elimination of HEL-specific cells upon antigen encounter in PPs (Supplemental Figure 3, D and E). This was particularly intriguing, as higher levels of BAFF have been associated with autoimmune diseases, including ulcerative colitis and Crohn's disease, and BAFF-transgenic mice have also been shown to develop autoimmunity (26-28). However, in our experimental system, overexpression of BAFF alone was not sufficient to breach tolerance against a gut-associated self-antigen.

$\mathrm{SW}_{\mathrm{HEL}}$ B cells undergo $V_{H}$ replacement of the knockin allele, which is the primary reason that only $20 \%-30 \%$ of the peripheral B cells are HEL specific. Therefore, to determine the maximal efficiency of negative selection in the absence of secondary recombination events, we crossed the $\mathrm{SW}_{\mathrm{HEL}}$ mice onto a Rag2-null background to obtain $\mathrm{SW}_{\mathrm{HEL}}\left(\operatorname{Rag} 2^{\mathrm{KO}}\right)$ mice. In this case, all peripheral $\mathrm{B}$ cells bind $\mathrm{HEL}$ and allow us to evaluate receptor downmodulation and apoptosis in straightforward manner relative to control mice lacking mDEL expression. Next, we reconstituted Villin ${ }^{\mathrm{Cre}+} \mathrm{mDEL}^{\text {loxP }}$ and control, Villin ${ }^{\mathrm{Cre}+}$ mice with $\mathrm{SW}_{\mathrm{HEL}}\left(\operatorname{Rag}^{\mathrm{KO}}\right)$ bone marrow to obtain RVillin ${ }^{\mathrm{Cre}+} \mathrm{mDEL}^{\mathrm{loxP}}\left(\operatorname{Rag}^{\mathrm{KO}^{\mathrm{KO}}}\right)$ and control, RVillin ${ }^{\mathrm{Cre}}\left(\operatorname{Rag}^{2 \mathrm{KO}}\right)$ mice. Remarkably, we observed a partial rescue in the number of HEL-specific B cells in PPs indicating an event of receptor editing in self-reactive B cells (Figure 4C). To confirm, if it was the RAG2 deficiency in self-reactive B cells leading to rescue, we repeated this experiment in mixed bone marrow chimeras of $\mathrm{SW}_{\mathrm{HEL}}\left(\right.$ Rag $\left.^{\mathrm{KO}}\right)$ and $\mu \mathrm{MT}$ mice to provide a functional pool of T cells. Remarkably, we obtained no difference in the number of HEL-specific B cells in RVillin ${ }^{\mathrm{Cre}+} \mathrm{mDEL}^{\text {loxP }}\left(\operatorname{Rag}^{\mathrm{KO}}\right)$ and control, $\mathrm{RVillin}^{\mathrm{Cre}+}\left(\operatorname{Rag}{ }^{\mathrm{KO}}\right)$ mice in the presence of absence of $\mathrm{T}$ cells (Figure 4, D-F). We further observed no changes in activation due to loss of Rag2 (Figure 4G). These results suggests that BCR engagement to self-antigen induces RAG, leading to $V_{H}$ replacement and a switch in specificity to avoid elimination.

Ectopic expression of BCL2 rescues survival of self-antigen-exposed self-reactive B cells. Next we tested whether a cell-intrinsic survival signal is capable of rescuing the survival of HEL-specific B cells in the gut. To further 
A

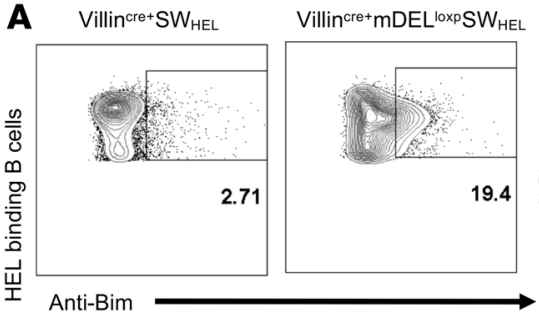

- Villin ${ }^{\text {cre }}$ SW $W_{\text {HEL }} \cdot V^{2}$ Vilin ${ }^{\text {cre }} \mathrm{mDEL} \mathrm{L}^{\text {loxp}} S W_{\text {HEL }}$

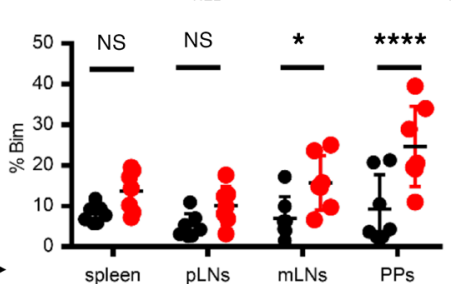

B

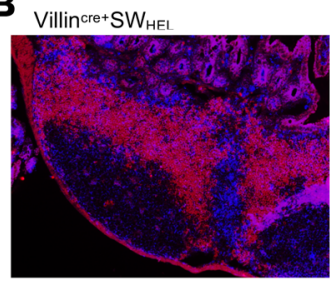

HEL Binding Bim
C RVillin ${ }^{\text {cre+ }}\left(\right.$ Rag2 $\left.^{\text {ко }}\right) \cdot$ RVillincre+mDEL $^{\text {loxp }}\left(\operatorname{Rag}^{\mathrm{ko}}\right)$

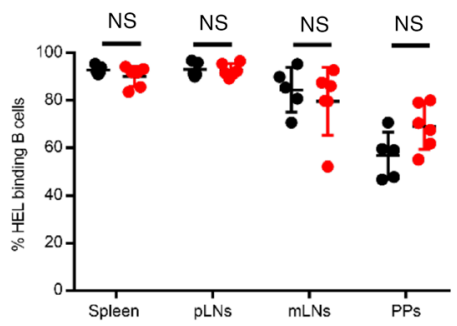

D $\operatorname{RVillin}^{\text {cre+ }}\left(\operatorname{Rag}^{\mathrm{KO}}\right)$

- RVillin ${ }^{\text {cret }} m D E L^{\text {loxp }}\left(\operatorname{Rag}^{\mathrm{KO}}\right)$
口 RVillin ${ }^{\text {Cre+ }}\left(\operatorname{Rag}^{\mathrm{KO}}+\mu \mathrm{MT}\right)$

$\square$ RVillin $^{\text {cre }}{ }^{m D E}{ }^{\text {loxp }}\left(\mathrm{Rag} 2^{\mathrm{KO}}+\mu \mathrm{MT}\right)$

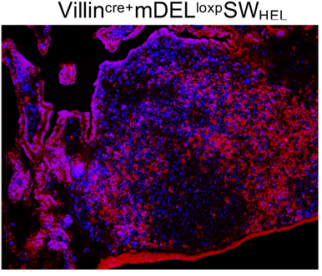

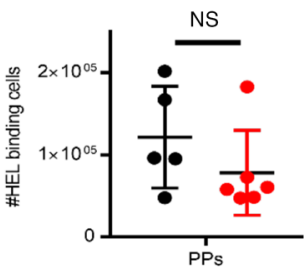

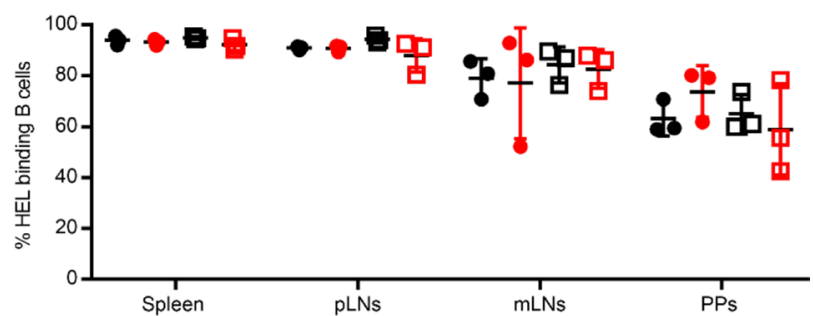

G

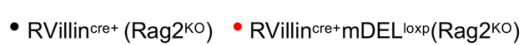
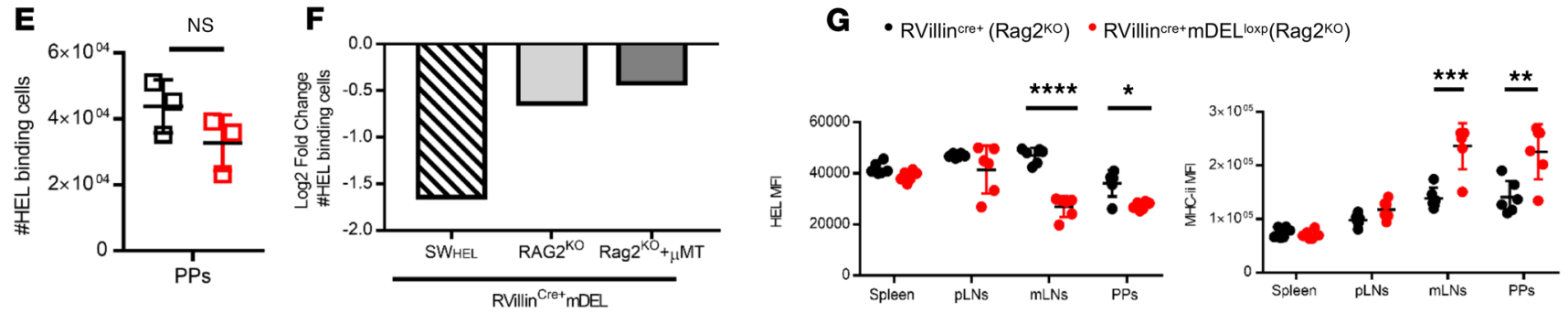

Figure 4. Self-reactive B cells undergo Bim-mediated apoptosis and Rag-mediated receptor editing. (A) Gated on B220+HEL ${ }^{+}$cells, dot plot displaying gain of Bim expression in HEL-specific cells upon antigen encounter in PPs and graph displaying the percentage of Bim ${ }^{+} \mathrm{HEL}-s p e c i f i c$ cells in spleens, pLNs, mLNs, and PPs from Villin ${ }^{\text {cree }} \mathrm{SW}_{\text {HEL }}$ and Villin ${ }^{\text {cre }} \mathrm{mDEL}^{\text {loxp }} S W_{\text {HEL }}$ mice. ${ }^{*} P=0.0442,{ }^{* * *} P<0.0001$. Data are representative of more than 3 experimental repeats and 7 mice per group. (B) Immunohistochemistry staining of HEL binding (cy3) and Bim (cy5) in PPs from Villin ${ }^{\text {cre+ }} \mathrm{SW}_{\text {HEL }}$ and $V_{i l l i n}{ }^{\text {cre }}+m D E L^{\text {loxp }} S W_{\text {HEL }}$ mice (original magnification, $\times 20$ ). Villin ${ }^{\text {cre }}$ and Villin ${ }^{\text {cret }} \mathrm{mDEL}^{\text {loxp }}$ mice were reconstituted with the bone marrow from $\mathrm{SW}_{\text {HEL- }}$ Rag2 ${ }^{\mathrm{KO}}$-transgenic mice (C) The frequency of $\mathrm{B} 22 \mathrm{O}^{+}$cells in the spleens, pLNs, $\mathrm{mLNs}$, and PPs and absolute numbers of HEL-specific B cells from PPs of RVillin ${ }^{\text {cre+ }}\left(\operatorname{Rag}^{\mathrm{KO}}\right)$ and RVillin ${ }^{\text {cre+ }} \mathrm{mDEL}^{\operatorname{loxp}}\left(\mathrm{Rag}^{\mathrm{KO}}\right)$ mice. (D) Gated on $\mathrm{B}^{2} 2 \mathrm{O}^{+}$cells, graph displaying the frequency of HEL-specific cells in the spleens,

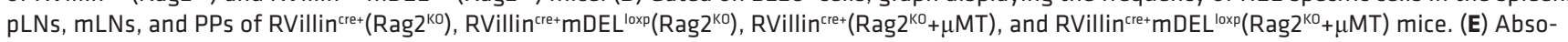
lute numbers of HEL-specific cells in PPs of RVillin ${ }^{\text {cret }}\left(\operatorname{Rag}^{\mathrm{KO}}+\mu \mathrm{MT}\right)$ and RVillin ${ }^{\text {cre }+} \mathrm{mDEL}^{\mathrm{loxp}}\left(\mathrm{Rag}^{2{ }^{\mathrm{K}}}+\mu \mathrm{MT}\right)$ mice. (F) Log fold change in the numbers of

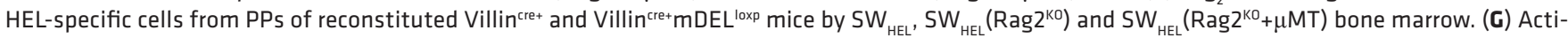

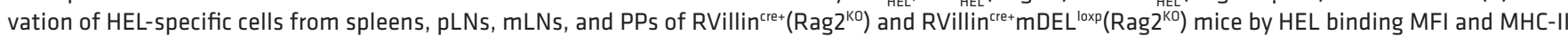
MFI. ${ }^{* * *} P<0.0001,{ }^{* *} P<0.005,{ }^{*} P=0.0253$. Data are represented of 4 mice group; experiments were performed 3 times for Rag $2^{\mathrm{Ko}}$ rescue. Grouped statistical analysis was performed by multiple $t$ test and 2-way ANOVA in Prism.

investigate this, we crossed $\mathrm{SW}_{\mathrm{HEL}}$ mice to the E $\mu$ - $B c l 2-22$-transgenic mouse line $\left[\mathrm{SW}_{\mathrm{HEL}}(B c l 2)\right]$ to allow B lineage-specific overexpression of the antiapoptotic protein $\operatorname{Bcl}-2(29,30)$. We reconstituted RVillin ${ }^{\mathrm{Cre}}$ $\mathrm{mDEL}^{\text {loxP }}\left[\mathrm{RVillin}^{\mathrm{Cre}} \mathrm{mDEL} \mathrm{L}^{\mathrm{loxP}}(B c l 2)\right]$ and control RVillin ${ }^{\mathrm{Cre}}\left[\mathrm{RVillin}^{\mathrm{Cre}}(B c l 2)\right]$ mice with bone marrow cells isolated from $\mathrm{SW}_{\mathrm{HEL}}(B c l 2)$ mice (Figure 5A). Mice were analyzed 8-10 weeks after reconstitution. Remarkably, ectopic BCL2 expression completely rescued the survival of self-reactive HEL-specific B cells in RVil$\operatorname{lin}^{\mathrm{Cr}} \mathrm{mDEL} \mathrm{L}^{\operatorname{loxP}}(B c l 2)$ mice compared with $\mathrm{RVillin}^{\mathrm{Cre}}(B c l 2)$ control mice (Figure 5, B and C). Moreover, the BCL2-expressing HEL-specific B cells showed downregulation of cell surface BCR as well as upregulation of CD86 and MHC-II that together represent features associated with cellular activation (Figure 5, D-F). Intriguingly, BIM protein levels were still upregulated in BCL2-overexpressing HEL-specific cells (Figure 5G), consistent with the fact that BCL2 counteracts the activity, but not the expression, of BIM protein (31). The upregulation of BIM in HEL-specific cells from RVillin ${ }^{\mathrm{Cre}} \mathrm{mDEL}^{\operatorname{loxP}}(B c l 2)$ mice also implies that, even in the presence of BCL2, HEL-specific self-reactive B cells in the context of a gut-associated self-antigen are primed to undergo apoptosis, and this process is aborted only by the downstream antiapoptotic effects of BCL2. Together, these results demonstrate that cell-intrinsic survival signals can rescue the terminal fate of self-reactive B cells in the gut. 
A

10Gy

B

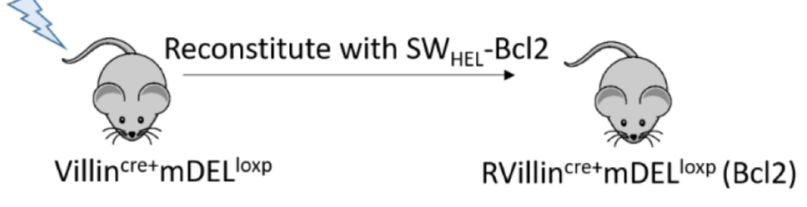

- RVillincre+ $(\mathrm{Bcl} 2)$

- RVillincre+mDEL ${ }^{\operatorname{loxp}}(\mathrm{Bcl} 2)$

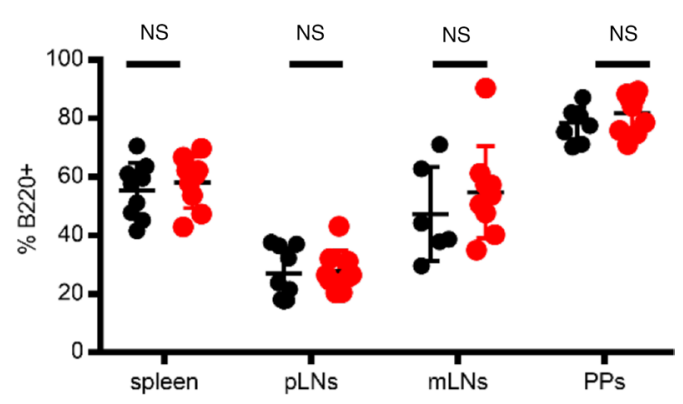

C

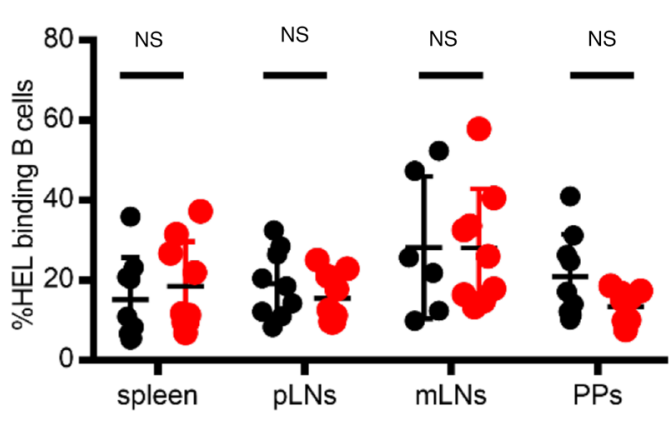

E

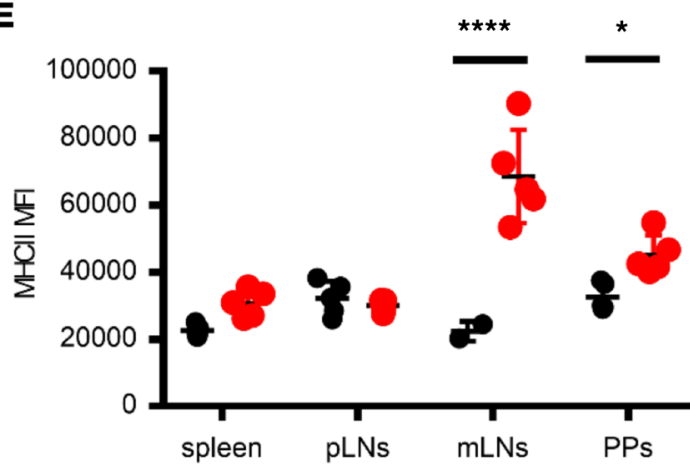

D

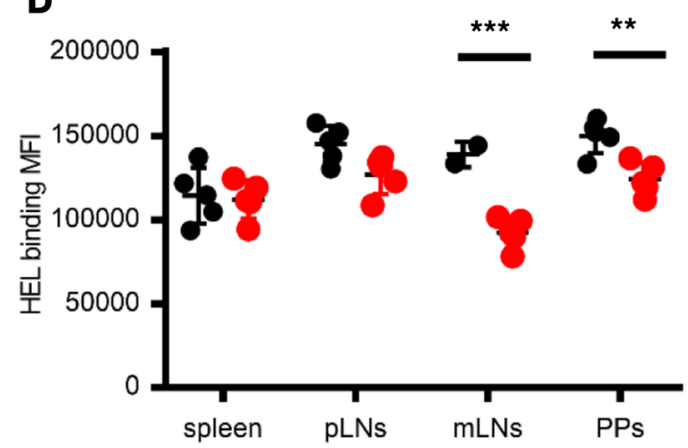

$\mathbf{F}$

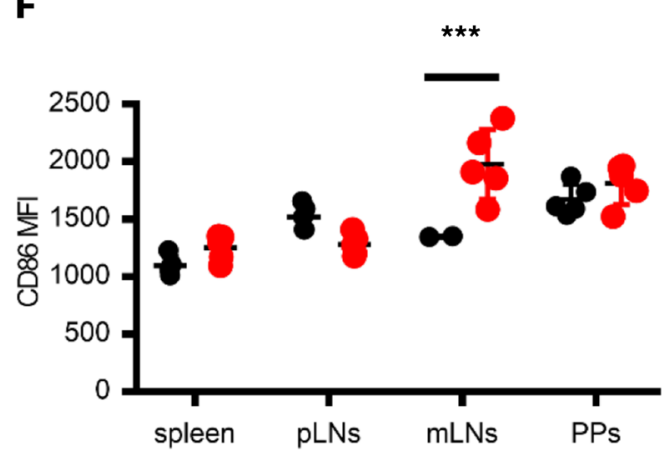

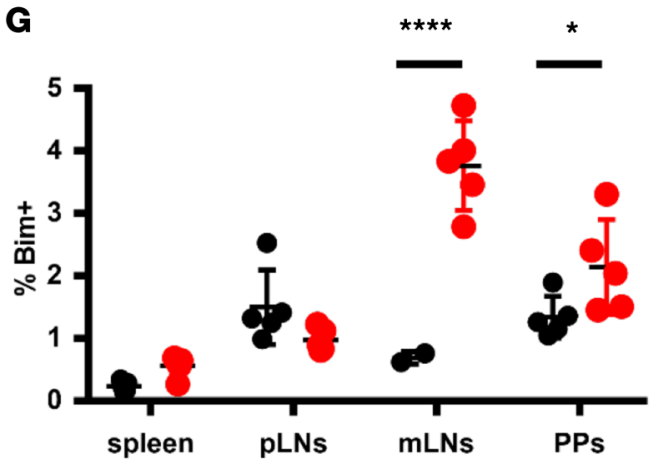

Figure 5. Ectopic expression of Bcl2 rescues the survival of self-reactive B cells in gut. (A) Schematic for experimental design to reconstitute Villin ${ }^{\text {cre+ }}$ and Villin ${ }^{\text {cre }}+m D E L^{\text {loxp }}$ mice with $\mathrm{SW}_{\text {HEL }}$-Bcl2-transgenic mice bone marrow. (B) Gated on lymphocyte population, graph displaying the frequency of $\mathrm{B}^{2} 2 \mathrm{O}^{+}$cells in spleens, $\mathrm{pLNs}, \mathrm{mLNs}$, and PPs of RVillin ${ }^{\text {cret }}(\mathrm{Bc} / 2)$ and RVillin ${ }^{\text {cre }}+\mathrm{mDEL}^{\text {loxp }}(\mathrm{Bc} / 2)$ mice. (C) Gated on $\mathrm{B}_{22 \mathrm{O}^{+}}$population, graph displaying $\mathrm{HEL}$-binding cell frequencies in the spleens, pLNs, mLNs, and PPs of RVillin ${ }^{\text {cre+ }}(\mathrm{Bcl})$ and RVillin ${ }^{\text {cre+ }} \mathrm{mDEL}^{\operatorname{loxp}}(\mathrm{Bcl} / 2)$ mice. MFI of (D) HEL binding, (E) MHC-II, and (F) CD86 on HEL-specific cells in the spleens, pLNs, $\mathrm{mLNs}$, and PPs of RVillin ${ }^{\text {cret }}(\mathrm{Bcl} / 2)$ and RVillin ${ }^{\text {cret }} \mathrm{mDEL} \mathrm{L}^{\text {loxp }}$

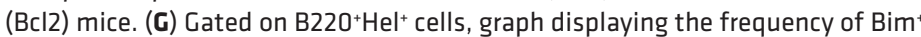
cells. ${ }^{* *} P<0.001,{ }^{* *} P<0.01$, ${ }^{* * *} P<0.0001,{ }^{*} P<0.05 ; n=9$ mice per group. Grouped statistical analysis was performed by multiple $t$ test.

Breach in B cell peripheral tolerance to gut-associated antigen develops gut inflammation. Since, ectopic expression of BCL2 rescued the survival of self-reactive B cells in GALT, we then closely examined the RVil$\operatorname{lin}^{\mathrm{Cre}} \mathrm{mDEL} \mathrm{L}^{\operatorname{loxP}}(B c l 2)$ mice for apparent signs of pathologies. First, we determined that the BCR isotype self-reactive B cells will switch in gut upon receiving survival signal by surface-staining HEL-specific cells. Interestingly, we observed an approximately 2.5-fold increase in HEL-specific IgA-expressing cells in the 
PPs of RVillin ${ }^{\mathrm{Cre}} \mathrm{mDEL} \mathrm{L}^{\mathrm{loxP}}(B c l 2)$ mice compared with the RVillin ${ }^{\mathrm{Cre}}(B c l 2)$ control mice (Figure 6A). Second, to determine if the fate of these self-reactive B cells is altered, we measured the BCR-specific antibody production in serum and fecal extracts. Interestingly, we observed a significant ( $\sim 1.5$ fold) increase in HEL-specific IgA antibody in the serum and fecal extracts, whereas a nonsignificant increase in HEL-specific IgG1 antibody was observed in sera of RVillin ${ }^{\mathrm{Cre}} \mathrm{mDEL}{ }^{\mathrm{loxP}}(B c l 2)$ mice when compared with $\mathrm{RVillin}^{\mathrm{Cre}}(B c l 2)$ mice (Figure 6, B and C). Remarkably, histological evaluation of the gut in RVillin ${ }^{\mathrm{Cre}} \mathrm{mDEL} \mathrm{L}^{\mathrm{loxP}}(B c l 2)$ mice showed several characteristic features of colonic inflammation that are also associated with human IBD. These included submucosa and mucosa infiltration by lymphocytes, flattening of crypts, and, in general, a higher degree of inflammation (Figure 6, C-E). Notably, these pathologies developed spontaneously, displaying higher pathological scores, and the other 2 mice (no. 922 and no. 500) showed milder but overt signs of pathologies (Table 1). Importantly, none of the RVillin ${ }^{\mathrm{Cre}} \mathrm{mDEL}^{\mathrm{loxP}}(B c l 2)$ control mice from the same cohort developed such conditions. Together, these observations suggest that intrinsic survival signals such as those provided by ectopic expression of $B c l 2$ cause a breach in peripheral tolerance in the gut, leading to development of overt inflammatory pathologies.

Transcriptional profiling of HEL-specific self-reactive $B$ cells reveals upregulation of TGF- $\beta$ signaling. To elucidate the molecular mechanism involved in rendering B cells tolerant to the self-antigen at the GALT, we performed transcriptional profiling. To do so, HEL-specific and non-HEL-specific B cells were sorted from spleens, mLNs, and PPs from 3 different Villin ${ }^{\text {cret }} \mathrm{mDEL}^{\text {loxp}} \mathrm{SW}_{\mathrm{HEL}}$ mice and then RNA-Seq was performed. The HEL-specific B cells from spleens were used as controls to demarcate the transcriptional profile in the absence of self-antigen encounter, and non-HEL-specific B cells from the spleen, mLNs, and PPs served as internal controls for defining tissue-specific gene signatures. We first performed hierarchical clustering analysis to identify the relative similarity between the transcriptional profiles of different samples Figure 7A. As expected, the HEL-specific self-reactive B cells, particularly those from the PPs and mLNs, clustered together; while the non-HEL-specific non-self-reactive B cells from mLNs and spleens as well as HEL-specific B cells from the spleens appeared more closely related to one another. The non-HEL-specific B cells in PPs showed some resemblance to HEL-specific B cells in PPs, likely because a subset among these cells undertakes a germinal center program and displays features of cell activation.

We then compared these data sets in various permutations to first identify differentially expressed gene (DEG) signatures in HEL-specific cells in PPs versus those present in mLNs and spleens. Our analysis identified 591 and 488 DEGs in HEL-specific cells in PPs compared with mLNs and spleen, respectively Figure 7B. Concurrently, we identified 926 and 862 DEGs in non-HEL-specific cells in PPs compared with mLNs and spleens (Supplemental Figure 4). We further used the HEL-specific and non-HEL-specific DEG signatures to perform MetaCore and Metascape pathway analysis, which revealed a total of 10 statistically significant unique molecular pathways differentially regulated among self-reactive HEL-specific B cells upon self-antigen exposure in PPs compared with mLN and spleens (Figure 7C). Similarly, a total of 16 differentially regulated molecular pathways were identified among non-HEL-specific B cells in PPs compared with mLNs and spleens, and these were used to determine tissue-specific changes (Figure 7D). These uniquely regulated pathways in HEL-specific and non-HEL-specific B cells at PPs were then compared with each other to delineate 8 unique molecular pathways that are specifically enriched among HEL-specific B cells upon self-antigen exposure (Figure 7E). Notably, among these pathways, our analysis revealed a significant enrichment of a TGF- $\beta$ signaling-induced network in HEL-specific cells in PPs. To investigate this further, we performed a Gene Set Enrichment Analysis using a panel of TGF- $\beta$ signature genes (identified by treatment of T cells with TGF- $\beta$ in culture) to test for the enrichment of TGF- $\beta$ signaling activity in HEL-specific B cells in PPs. Remarkably, we obtained a robust and significant enrichment of TGF- $\beta$ signature genes among DEGs in HEL-specific B cells in PPs when compared with HEL-specific B cells in spleens (Figure 8A). Moreover, we also observed a trend among DEGs identified upon comparison between HEL-specific and non-HEL-specific B cells at PPs for enrichment of TGF- $\beta$ signature genes (Figure $8 \mathrm{~B}$ ). Furthermore, we observed the enrichment of TGF- $\beta$ signature genes in HEL-specific cells from PPs from Villin ${ }^{\text {cret }} \mathrm{mDEL}^{\text {loxp}} \mathrm{SW}_{\mathrm{HEL}}$ mice when compared with HEL-specific cells from Villin ${ }^{\mathrm{Cre}+} \mathrm{SW} \mathrm{HEL}_{\text {mice }}$ by RT-PCR (Figure $8 \mathrm{C}$ ). Collectively, using systematic and stringent analysis criteria, our studies revealed specific upregulation of the TGF- $\beta$ signaling pathway in HEL-specific B cells following exposure to self-antigen in GALT.

We also performed transcriptional profiling of HEL-specific B cells isolated from PPs, mLNs, and spleens of RVillin ${ }^{\mathrm{Cre}} \mathrm{mDEL} \mathrm{L}^{\text {loxP}}(B c l 2)$ mice to identify molecular pathways that are deregulated upon breaching of B cell tolerance in the gut. As described above, we identified DEGs in HEL-specific B cells from PPs 
A

RVillincre+(BCL2)

RVillincre+mDEL ${ }^{\operatorname{loxp}}(\mathrm{BCL} 2)$

- RVillin ${ }^{\text {cre }}(B C L 2) \bullet$ RVillincre+mDEL $^{\operatorname{loxp}}(B C L 2)$
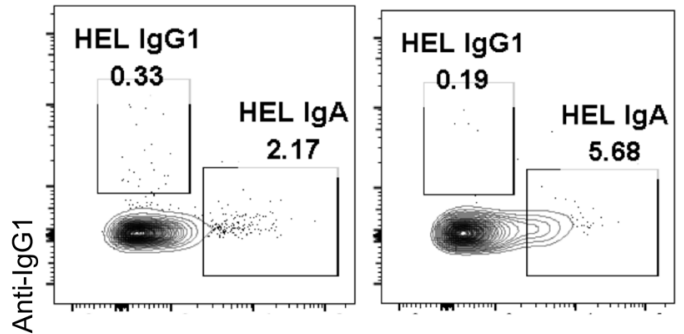

Anti-lgA

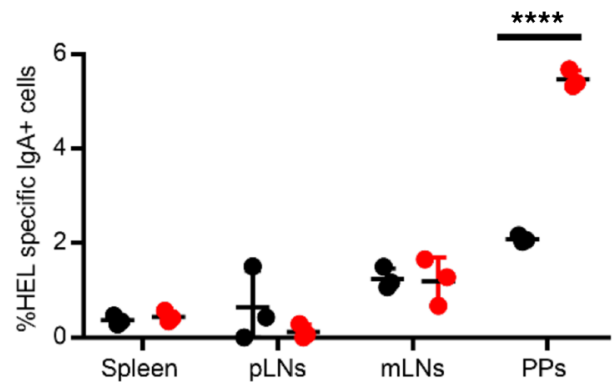

B

- RVillincre+(BCL2) - RVillincre+mDEL ${ }^{\text {loxp }}(B C L 2)$
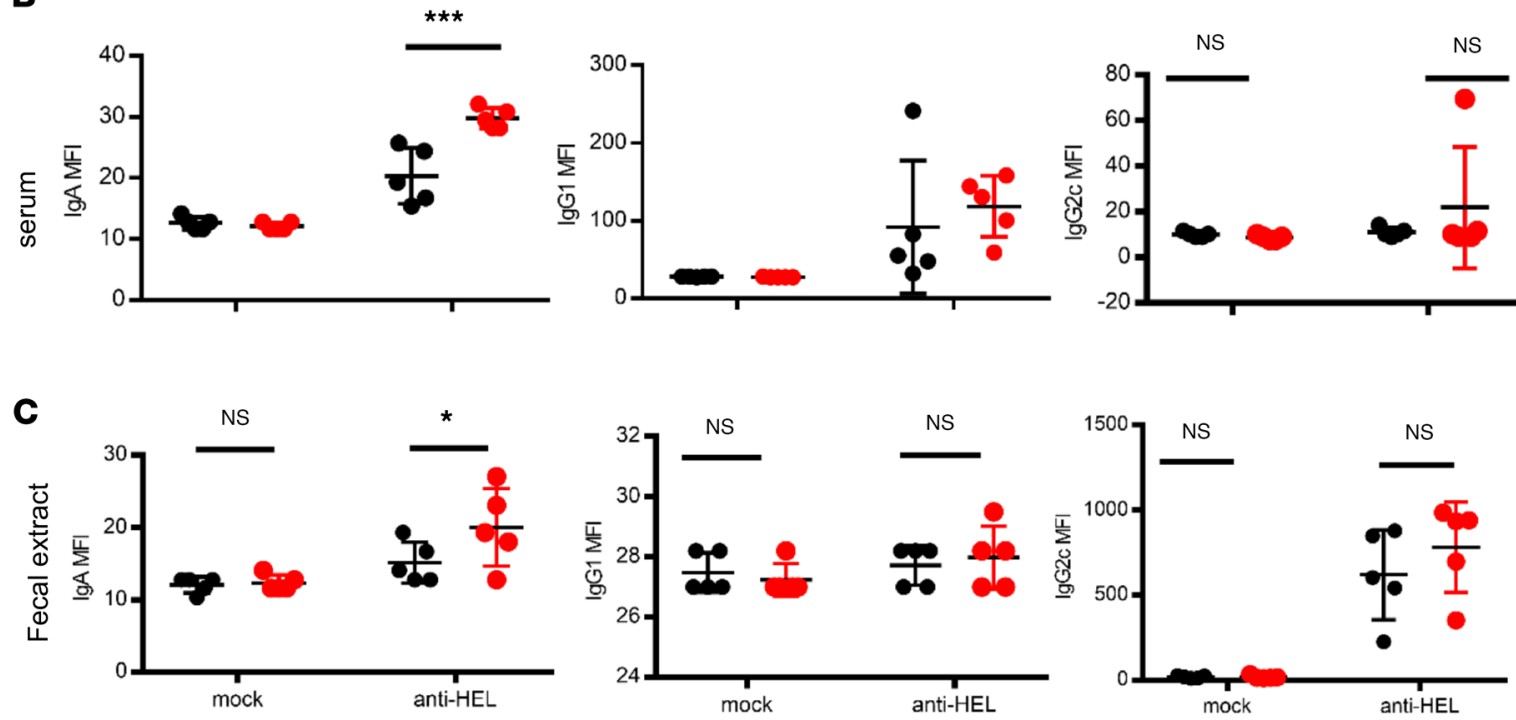

D

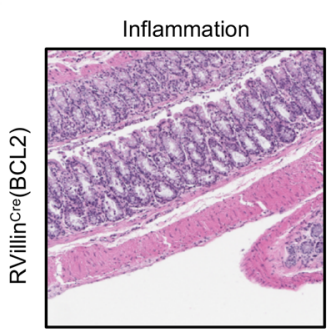

Muscularis

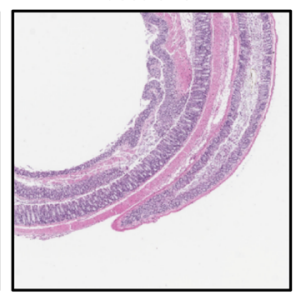

Villus

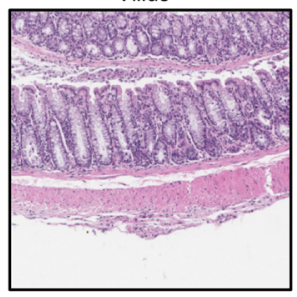

E
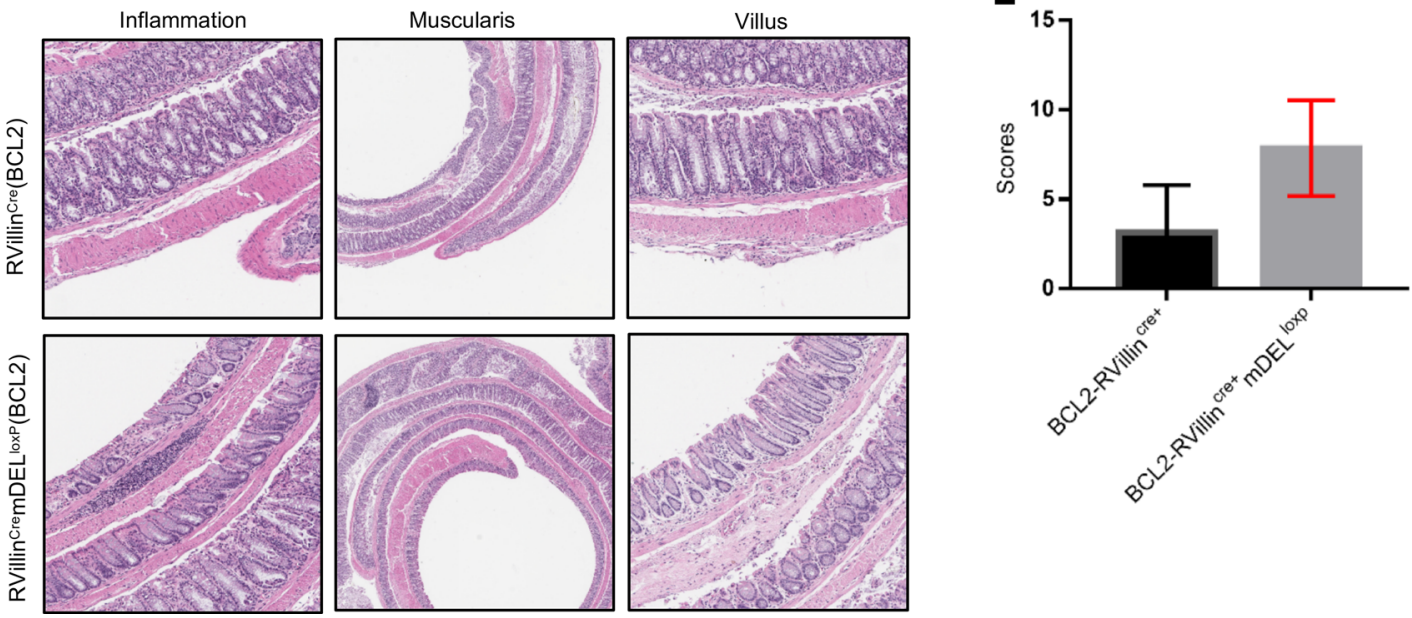

Figure 6. Deregulation of $\mathbf{B}$ cell tolerance in gut leads to IBD-like disease. (A) Flow contour plot showing the IgG1- and IgA-switched HEL-specific cells in the PPs and graph showing the frequency of HEL-specific IgA-switched cells in the spleens, pLNs, mLNs, and PPs of RVillin ${ }^{\text {cre }}(\mathrm{Bcl} 2)$ and RVillin $^{\text {cre }}$ mDEL $^{\text {loxp }}$ (BcI2) mice. The MFI of HEL-specific anti-IgA, anti-IgG1, and IgG2c (B) in serum and (C) in fecal extracts of RVillin cret $(B c \mid 2)$ and

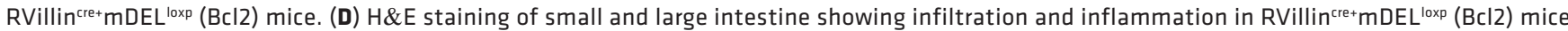
(original magnification, $\times 5$ [muscularis]; $\times 20$ [inflammation and villus]). (E) The gut histological scoring of $n=6$ and $n=7$, respectively, per group of RVil$\mathrm{lin}^{\text {cret }}(\mathrm{Bcl})$ and RVillin ${ }^{\text {cret }} \mathrm{mDEL} \mathrm{Lxp}^{\text {loxp }}(\mathrm{Bc} / 2)$ mice. 
Table 1. Histology scores and criteria

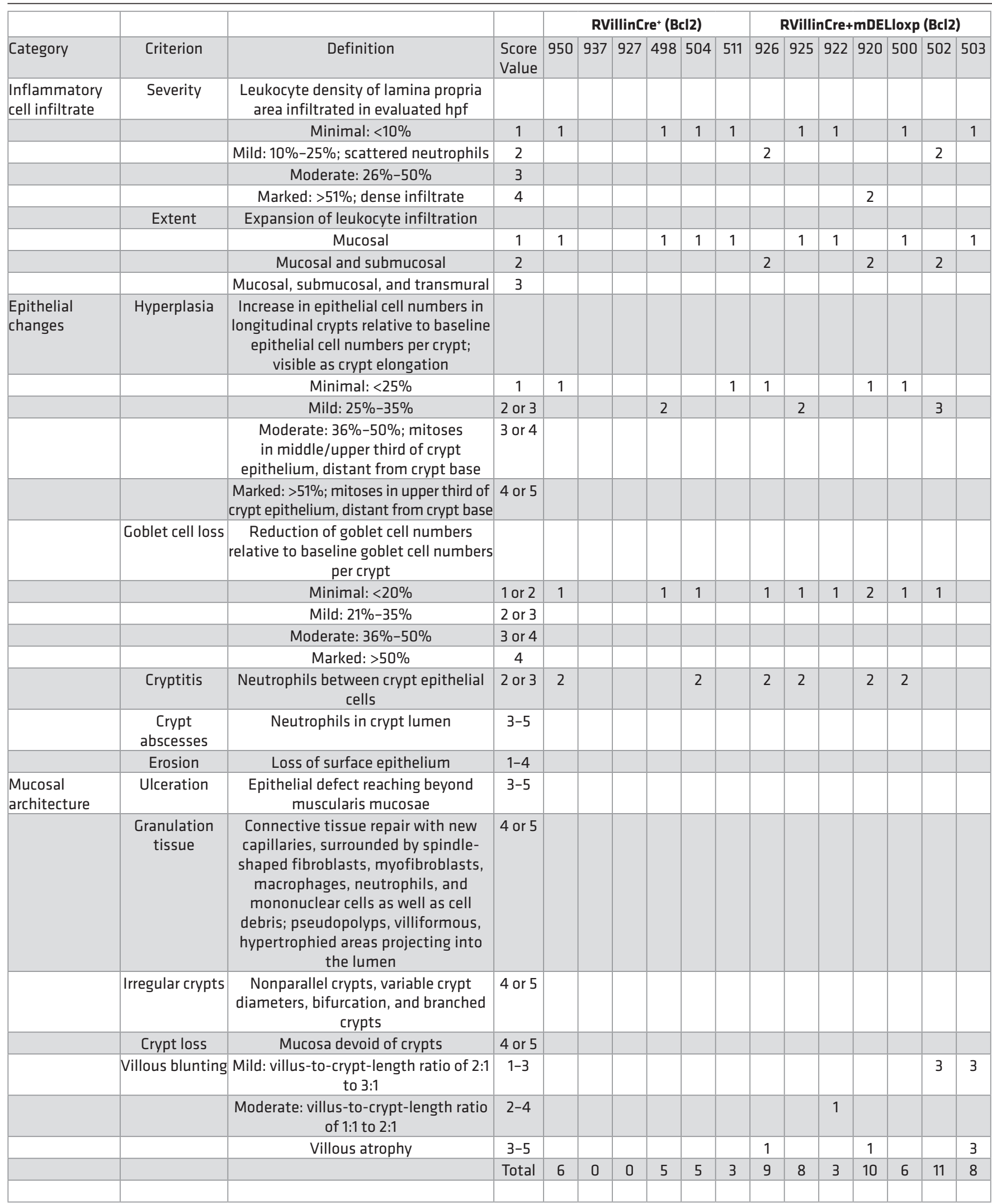

H\&E staining of the duodenum, small intestine, large intestine, and colon was performed. Slides were scored blinded based on the criteria described. Six mice in the RVillin ${ }^{\text {cret }}(\mathrm{Bcl} 2)$ control group and seven mice in the RVillin ${ }^{\text {cre }}+\mathrm{mDEL}^{\text {loxp }}(\mathrm{Bcl} 2)$ experimental group were scored. 
A

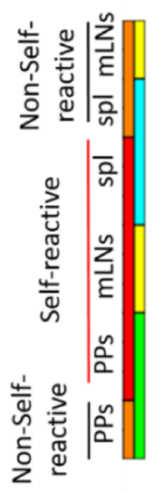

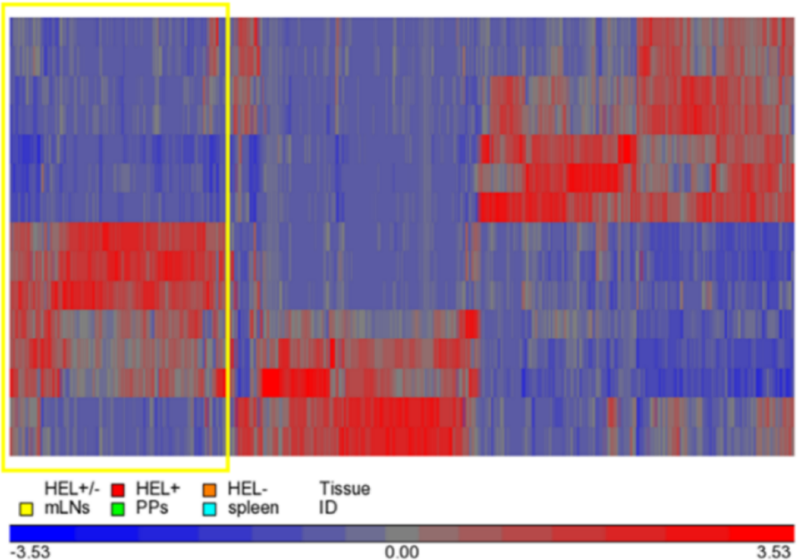

B

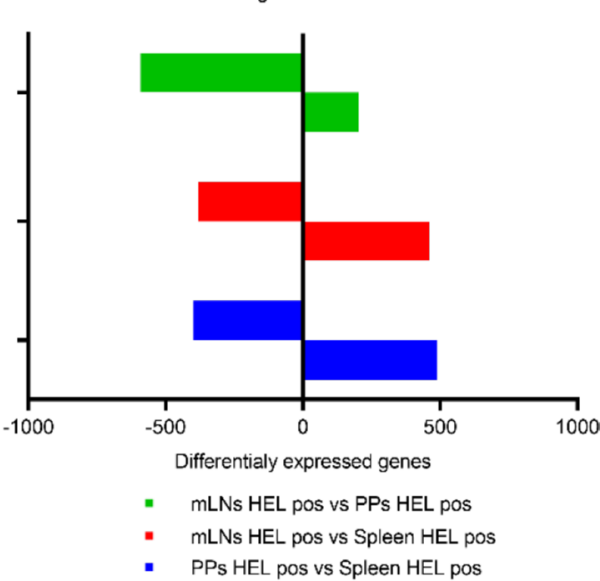

C

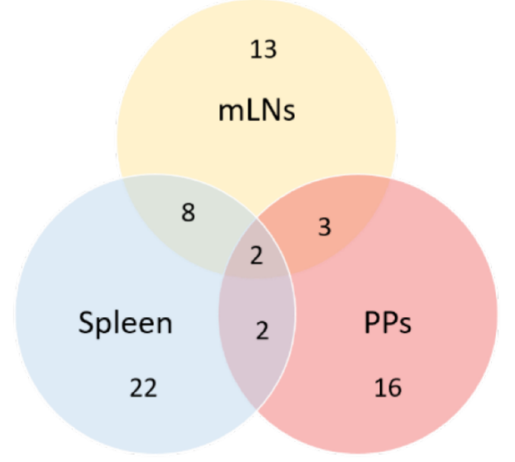

Pathways enriched in Non-HEL specific cells
D

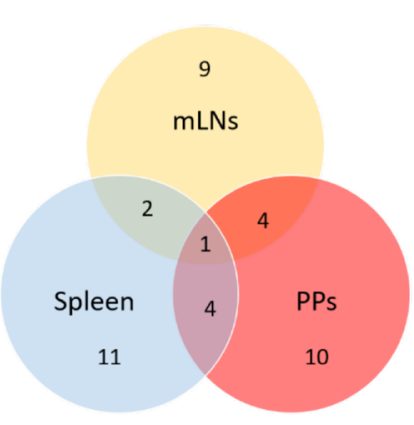

Pathways enriched in HEL specific cells mitotic cell cycle process

Cell Cycle Checkpoints

microtubule cytoskeleton organization

$\mathrm{T}$ cell activation

G2/M Transition

Th17 cell differentiation

Hemostasis

lymphocyte activation involved in immune

response

Biological oxidations

steroid metabolic process

monocarboxylic acid metabolic process actin filament-based process

Glutathione metabolism

intestinal absorption

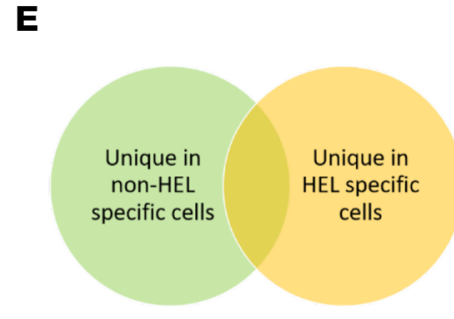

PPs
Ligand-dependent activation of the ESR1/AP-1 pathway

Putative pathways of hormone action in neurofibromatosis type 1

GM-CSF signaling

TGF-beta-dependent induction MAPK

Protein processing in endoplasmic

reticulum

Signaling by the B Cell Receptor (BCR)

regulation of endocytosis

(ER)-localized multiprotein complex, Ig heavy chains associated

Figure 7. TGF- $\beta$ signaling is enriched in self-reactive B cells upon antigen encounter in PPs. (A) Heatmap of supervised hierarchical clustering of differentially expressed genes (DEGs) in self-reactive B cells ( $\mathrm{HEL}+\mathrm{ve}$ ) or normal $B$ cells (HEL-ve) in spleens, $\mathrm{mLNs}$, and PPs isolated from Villin ${ }^{\text {cre }} \mathrm{m}$ $\mathrm{DEL}^{\text {loxp }} \mathrm{SW}_{\text {HEL }}$ mice. (B) The number of genes significantly $(P=0.01,1.5$-fold) over- or underexpressed in self-reactive $B$ cells from spleen, $\mathrm{mLNs}$, and PPs. Significant DEGs were run on MetaCore pathway analysis. (C) Venn diagram of common or unique molecular pathways significantly $(P<0.05)$ enriched in non-HEL-specific cells isolated from spleens, $\mathrm{mLNs}$, and PPs. (D) Venn diagram of common or unique molecular pathways enriched in HEL-specific cells isolated from spleens, $\mathrm{mLNs}$, and PPs $(P<0.05)$. Among the unique pathways identified in $\mathbf{C}$ and $\mathbf{D}$ in PPs $(\mathbf{E})$ are common or unique molecular pathways and a list of unique molecular pathways enriched in non-HEL and HEL-specific cells in PPs.

compared with those in mLNs and spleens. Our analysis revealed a total of 232 genes upregulated and 138 genes downregulated in HEL-specific B cells in the PPs compared with spleens, and these were used to perform MetaCore pathway analysis. Once again, we observed activation of the TGF- $\beta$ signaling pathway in PP HEL-specific B cells (Supplemental Figure 5), implying that Bcl2 rescues the survival of self-reactive 
cells at GALT in a cell-intrinsic manner. We then identified DEGs in HEL-specific cells isolated from RVillin ${ }^{\text {Cre }} \mathrm{mDEL}^{\text {loxp }}(B c l 2)$ mice when compared with HEL-specific cells from Villin ${ }^{\text {cret }} \mathrm{mDEL}^{\text {loxp }} \mathrm{SW}_{\mathrm{HEL}}$ mice. Consistent with the development of inflammatory pathologies in $\mathrm{RVillin}{ }^{\mathrm{Cre}} \mathrm{mDEL} \mathrm{L}^{\operatorname{lox}}(B c l 2)$ mice, our analysis unveiled pathways involved in the activation of inflammatory response. The HEL-specific cells from PPs displayed enrichment of an immune network for IgA production (Figure 8, D and E). This is in line with our findings that ectopic expression of $B c l 2$ rescues the survival of self-reactive B cells at GALT and induces BCR isotype switch to IgA and cellular differentiation.

Inhibition of TGF- $\beta$ signaling enhances the survival of the self-reactive B cells after gut-associated antigen encounter. Our transcriptional profiling and analysis of HEL-specific self-reactive B cells in GALT showed activation of the TGF- $\beta$ signaling pathway upon self-antigen encounter. The TGF- $\beta$ signaling pathway is induced upon binding of TGF- $\beta$ to TGF- $\beta$ receptor type 1 and 2 (TGF $\beta$ R1/2), leading to internalization of receptors. To confirm this, we stained the HEL-specific cells from RVillin ${ }^{\mathrm{Cre}} \mathrm{mDEL}^{\mathrm{loxP}}(B c l 2)$ and RVillin ${ }^{\mathrm{Cre}}(B c l 2)$ control mice. Interestingly, we observed a significant approximately 2.5- to 4-fold downregulation of TGF $\beta$ R1 in HEL-specific cells from spleens, pLNs, mLNs, and PPs (Figure 9A). This was in line with our previous finding in Figure 6A that HEL-specific cells in RVillin ${ }^{\mathrm{Cre}} \mathrm{mDEL}^{\text {loxP }}(B c l 2)$ mice have a survival advantage and switch to IgA. We next tested whether inhibition of TGF- $\beta$ signaling could rescue the survival of self-reactive HEL-specific cells in GALT. For these studies, we took a pharmacological approach and used a TGF $\beta$ R1/2-specific inhibitor, LY2109761, to inhibit TGF- $\beta$ signaling. We isolated splenic B cells from $\mathrm{SW}_{\mathrm{HEL}}$ mice that constituted a mixture of HEL-specific and non-HEL-specific $\mathrm{B}$ cells and cultured them in the presence of TGF $\beta$ R1/2 inhibitor or DMSO for 2 hours. After 2 hours, we washed and labeled the TGF $\beta$ R1/2 inhibitor- or DMSO-treated cells with cell trace dyes, CFSE, and Efluor670 or CTV dye, respectively (Figure 9B and Supplemental Figure 7). The TGF $\beta$ R1/2 inhibitor- or DMSO-treated and differentially labeled cells were then mixed together and intravenously injected into Villin ${ }^{\text {cre }} \mathrm{mDEL}^{\text {loxp }}$ mice. Mice were analyzed 72 hours after injections for relative proportions of transferred cells in spleens, mLNs, pLNs, and PPs. Interestingly, we observed significantly higher frequencies of HEL-specific B cells treated with TGF $\beta$ R1/2 inhibitor compared with DMSO-treated HEL-specific cells within the spleens, mLNs, pLNs, and PPs of the same mice (Figure 9B). Importantly, the frequencies of non-HEL-specific B cells treated with TGF $\beta R 1 / 2$ inhibitor were unaltered when compared with non-HEL-specific B cells treated with DMSO (Figure 9B). To ratify the activity of drug at 72 hours after injection we measured p-smad2/3 levels and observed significant, approximately 1.5- to 10-fold, downregulation in TGF $\beta \mathrm{R} 1 / 2$ inhibitor-treated HEL-specific cells from spleens, mLNs, and PPs (Figure 9C). The TGF $\beta R 1 / 2$ inhibitor-treated HEL-specific cells compared with DMSO-treated cells showed upregulation of CD69, an activation gene known to be suppressed by TGF- $\beta$ signaling (32), and showed higher levels of the cell migration marker, S1PR1, indicating less B cell retention in gut (Figure 9D). Overall, we observed an increase in frequencies of HEL-specific B cells, not just in PPs and mLNs, but also in pLNs and spleens, suggesting that, once rescued, the HEL-specific B cells readily recirculate through secondary lymphoid tissues. Together, our results here demonstrate that inhibition of TGF- $\beta$ signaling in a B cell-intrinsic manner rescues the survival of self-reactive B cells in the GALT, demonstrating a critical role for TGF- $\beta$ signaling in regulating B cell tolerance at GALT.

\section{Discussion}

The GALT is a complex microenvironment, in which B cells are challenged by a vast variety of harmless and pathogenic antigens. Our understanding of how B cells discriminate between these different antigens to either become ignorant or generate functional immune responses is quite limited. In our studies here, we developed a potentially novel mouse model to study the interaction of self-reactive B cells with cognate autoantigen in the gut. Our model mimics physiological scenarios, where only a small fraction $(10 \%-20 \%)$ of B cells harboring self-reactive BCR develop in the bone marrow and egress into the periphery. Notably, our studies unraveled robust tolerance mechanisms that rapidly abolished self-reactive B cells in the gut to suppress the development of overt pathologies. Delivery of cell-intrinsic survival signal by ectopic expression of $B c l 2$ rescued the terminal fate of autoreactive B cells and caused inflammation in gut. We performed transcriptomics analysis and used stringently curated filtering criteria to identified specific activation of TGF- $\beta$ signaling in self-reactive -HEL-specific B cells that contributed to the elimination of self-reactive B cells in the gut. In our studies here we observed the induction of tolerance to an autoantigen that is expressed on the cell surface of intestinal epithelial cells. It will be interesting to investigate whether similar mechanisms exist to induce tolerance against cross-reactive self-antigens from commensal microbiota and dietary factors in gut. 

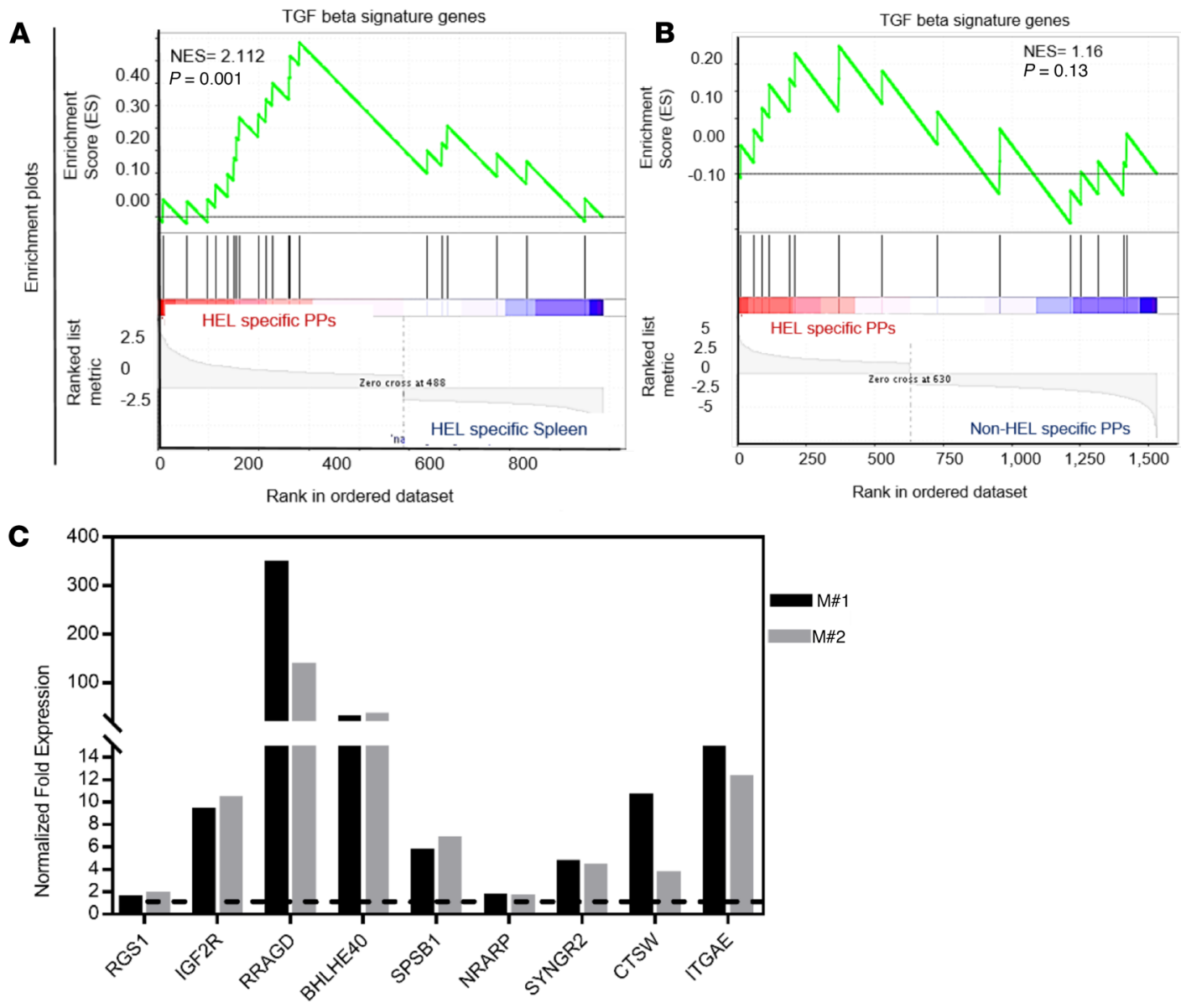

D

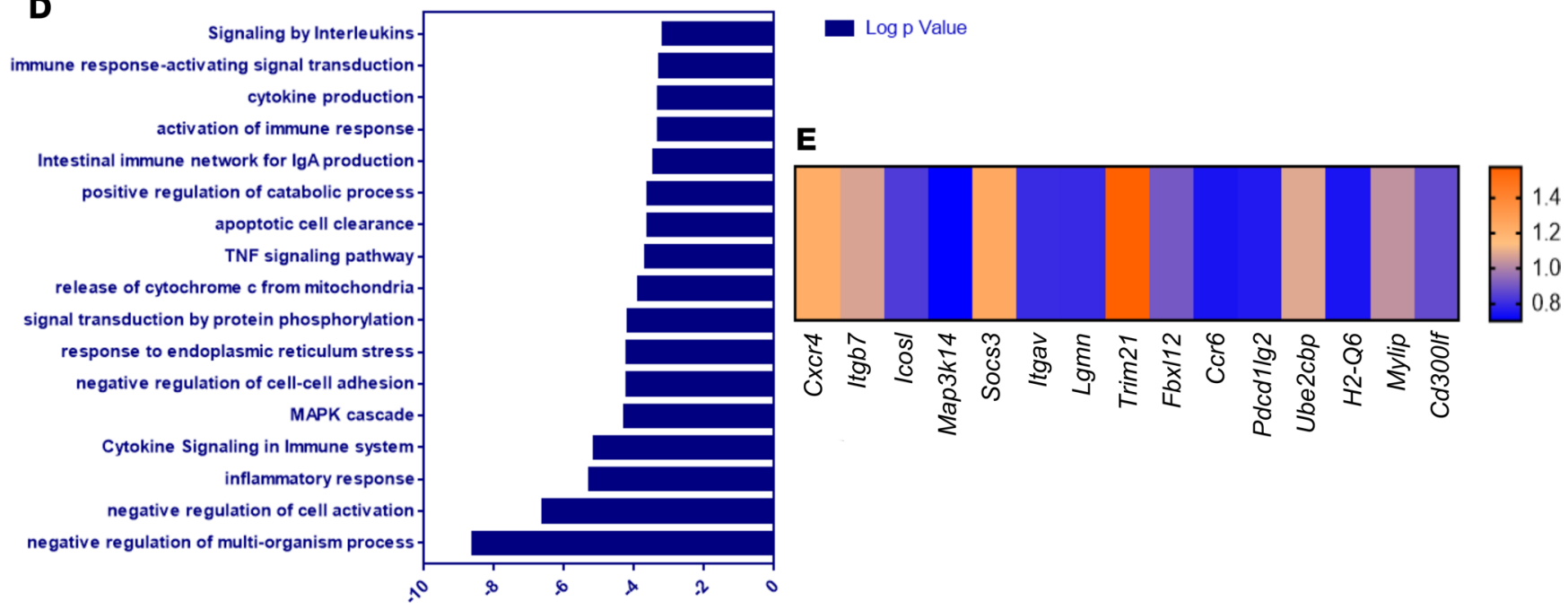

Figure 8. BCL2 induces an IgA immune network in self-reactive B cells. Gene set enrichment of TCF- $\beta$ signature genes (CSE7460) (A) consisting of DEGs in HEL-specific cells from PPs versus spleen and (B) consisting of DEGs in HEL-specific PPs versus non-HEL-specific PPs. (C) Fold expression of 9 genes in HEL-specific cells from PPs of RVillin ${ }^{\text {cret }}$ and RVillin ${ }^{\text {cre }}+m_{D E L} L^{\text {loxp }}$ mice (these genes were picked from TGF- $\beta$ signature genes; GSE7460). (D) List of pathways enriched in HEL-specific cells isolated from PPs of RVillin ${ }^{\text {cret }}$ mDEL $^{\text {loxp }}$ (Bcl2) mice verus HEL-specific cells from isolated from PPs from

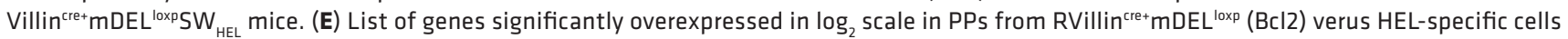
from isolated from PPs from Villin ${ }^{\text {cret }} \mathrm{mDEL}^{\text {loxp }} \mathrm{SW}_{\text {HEL }}$ mice from intestinal immune network for IgA production $(P<0.05) . n=3 \mathrm{HEL}$-specific samples, $n$ $=2$ for non-HEL-specific samples, and $n=3$ for RVillin ${ }^{\text {cre }} \mathrm{mDEL}^{\text {loxp }}(\mathrm{Bc} / 2)$. 
A

RVillinCre+mDEL (Bcl2)

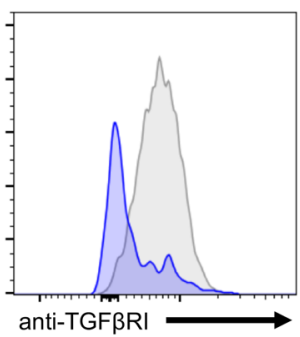

C

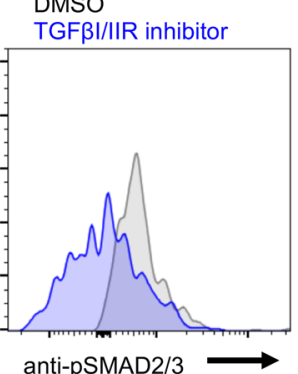

anti-pSMAD2/3
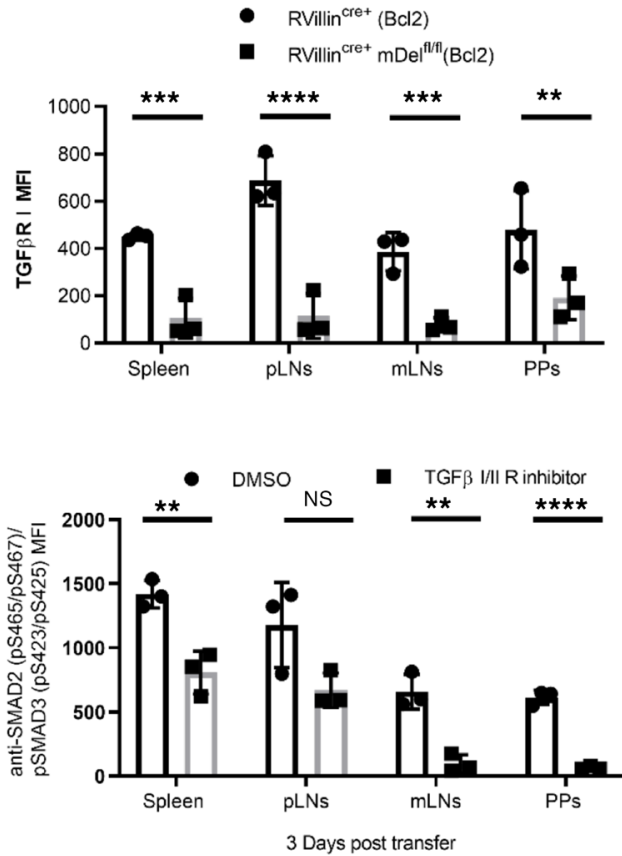

- DMSO

- TGF $\beta$ I/II R inhibitor

D

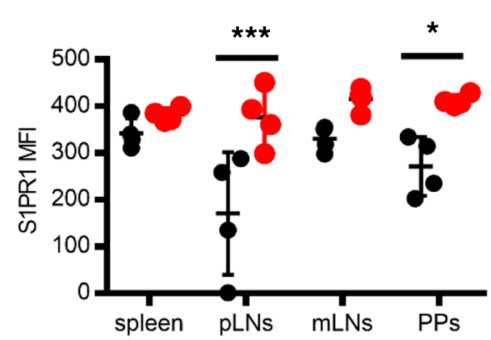

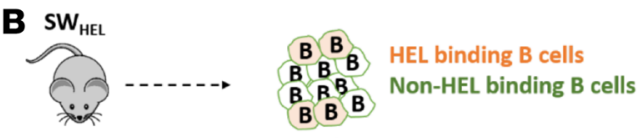

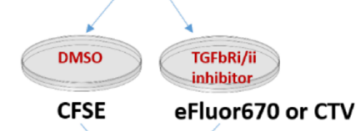

CFSE

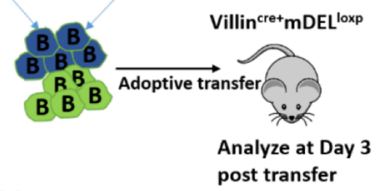

DMSO

TGF $\beta$ I/II R inhibitor

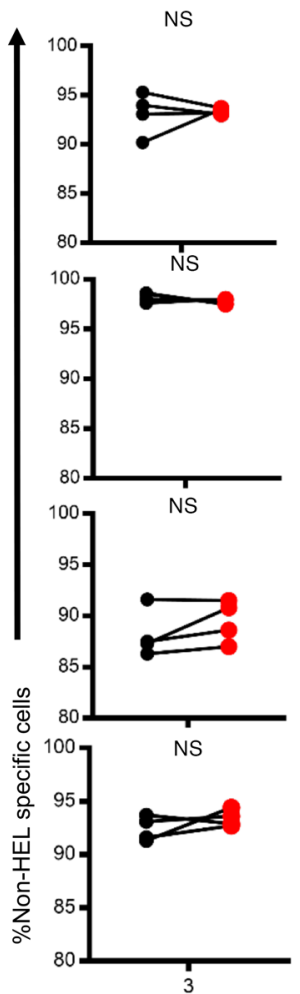

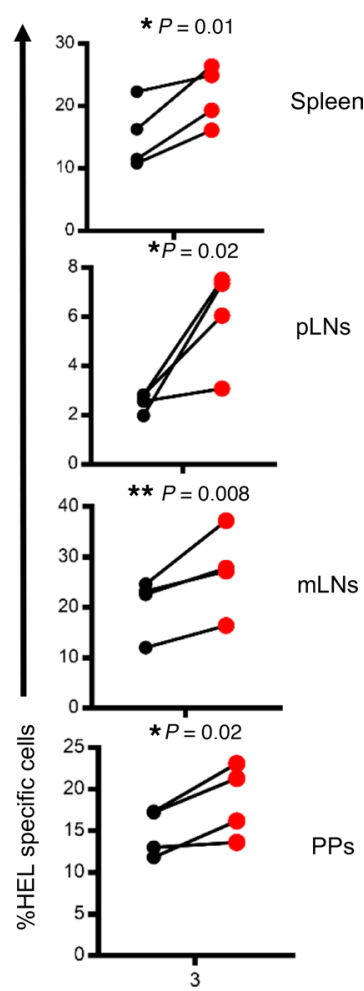

Figure 9. Inhibition of TGF- $\beta$ signaling rescues self-reactive $\mathbf{B}$ cells upon antigen encounter in gut. (A) Histogram and graph displaying TCF $\beta R I$ expression

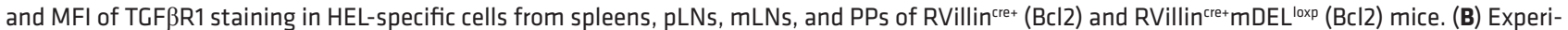
mental design schematic for study of the role of TCF- $\beta$ signaling in self-reactive B cells. Gated on $\mathrm{B}_{2} 2 \mathrm{O}^{+}$, the left column shows the percentage of CFSE ${ }^{+}$ (non-HEL-specific cells) and right column shows the percentage of eFLuor670+ cells in spleens, pLNs, mLNs, and PPs. (C) Histogram and graph displaying the $\mathrm{p}-\mathrm{Smad} 2 / 3$ expression and MFI of $\mathrm{p}-\mathrm{Smad} 2 / 3$ staining, as measured by flow cytometry in DMSO- and TCF $\beta \mathrm{I} / \mathrm{II} \mathrm{R}$ inhibitor-treated HEL-specific cells from spleen, pLNs, mLNs and PPs Villin ${ }^{\text {cret }}$ and Villin ${ }^{\text {cre }}$ mDEL $^{\text {loxp }}$ mice 72 hours after adoptive transfer. Graph of HEL-specific cells treated with DMSO or TCF $\beta I / I I ~ R$ inhibitor in spleens, pLNs, mLNs, and PPs (D) of CD69 MFI and S1PR1 MFI. The statistical analysis was done by paired $t$ test in Prism. ${ }^{* * *} P<$ $0.0001,{ }^{* *} P=0.0002,{ }^{* *} P=0.0077,{ }^{*} P=0.0105, n=4$ and experiment was repeated 3 times.

Our studies reveal that similar to receptor editing and clonal deletion of self-reactive B cells during central tolerance induced in bone marrow, the self-reactive B cells in the gut undergo BCR rearrangement and apoptosis following encounter with its autoantigen. Therefore, the induction of receptor editing and apoptosis represents the major mechanism contributing to peripheral tolerance in the gut. Our studies identify PPs as the primary inductive site where B cells are rapidly eliminated. However, how the self-reactive BCR receives, relays, and delivers an apoptotic or BCR rearrangement signal upon autoantigen encounter in the gut remains unclear. Perhaps, the specific cytokine milieu in the PPs contributes to this outcome, in which BCR engagement with an autoantigen without relevant $\mathrm{T}$ cell help 
translates to propagation of a death signal in self-reactive B cells. Yet, the signal that directs BCR rearrangement in the gut is still not understood.

Mechanistically, our studies identify activation of the TGF- $\beta$ signaling pathway in HEL-specific self-reactive $\mathrm{B}$ cells in the gut leading to their rapid elimination. Pharmacological inhibition of TGF- $\beta$ signaling by using an inhibitor specific to TGF $\beta$ R1/R2 reversed these phenotypes, promoted the survival of self-reactive B cells in the gut, and led to expression of chemokines that allowed homing of self-reactive B cells to other peripheral tissues. The TGF- $\beta$ signaling pathway is shown to have pleiotropic effects on B cells (33-40). In mucosal tissues, TGF- $\beta$ signaling is known to be crucial for IgA production, where it cooperates with CD40 ligand and other cytokine signals delivered by $\mathrm{T}$ cells to induce class switch recombination in B cells (37). In human B cells lines (and also in mouse B cells), TGF- $\beta$ signaling induces apoptosis by repressing the expression of the antiapoptotic protein BCL-XL and by directly inducing the expression of the proapoptotic protein PUMA $(39,40)$. TGF- $\beta$ signalinginduced apoptosis in B cells is shown to occur in an autocrine manner $(35,36)$, and PP B cells are known to produce significant amounts of TGF- $\beta$ (33). Whether and how TGF- $\beta$ signaling functions in an autocrine manner in self-reactive HEL-specific B cells to deliver a proapoptotic signal still remains unclear. It is worth pointing out that we observed higher mRNA expression of TGF $\beta$ R1 and TGF $\beta R 2$ in self-reactive HEL-specific B cells in PPs compared with non-HEL-specific B cells (Supplemental Figure 6). However, due to lack of appropriate reagents, we were not able to test the changes in protein expression of TGF $\beta$ R1 and TGF $\beta$ R2. Perhaps the higher levels of TGF $\beta R 1$ and TGF $\beta R 2$ make self-reactive HEL-specific B cells more sensitive and responsive to TGF- $\beta$ levels in PPs. Interestingly, a recent study showed that activation of TGF- $\beta$ signaling in PP B cells leads to upregulation of the latent TGF- $\beta$-binding protein, GARP (41), which can induce production of active TGF- $\beta$ from latent TGF- $\beta$ in human B cells to boost IgA production (42). Even though, we did not observe any significant differences in the expression of Lrrc32, the gene encoding GARP, in self-reactive B cells compared with non-self-reactive B cells in PP, it is reasonable to speculate that higher expression of GARP in PP B cells may contribute to higher levels of active TGF- $\beta$ in the PP tissue microenvironment, which may act in a paracrine axis to induce tolerance. Consistent with this notion, GARP was shown to function in a B cell-specific manner to regulate the induction of peripheral tolerance in a model of oral sensitization (41). Taken together, our studies presented here highlight TGF- $\beta$ signaling as a critical checkpoint for induction of peripheral tolerance in self-reactive B cells in the gut. In line with our findings, extrinsic influences, such as excessive BAFF-producing macrophages, do not rescue or alter the fate of the self-reactive B cells. However, provision of a stronger prosurvival signal, such as BCL2, in RVillin ${ }^{\mathrm{Cre}} \mathrm{mDEL} \mathrm{wt}^{\mathrm{wt}}(\mathrm{Bcl})$ mice, completely rescues self-reactive cells. In addition to the activation status being retained, the TGF- $\beta$ signaling pathway was also enriched in HEL-specific cells in PPs. Further, the percentage of $\mathrm{BIM}^{+}$self-reactive B cells was still significantly high, indicating that BCL2 only rescues the phenotype but does not alter BCR signaling downstream. Moreover, an interesting finding of this study is that just upon receiving survival signaling these cells switched to $\operatorname{IgA}$ and an increase in HEL-specific IgA antibody was observed.

Our studies here demonstrate that B cell-intrinsic activation of TGF- $\beta$ signaling is important for induction of peripheral tolerance in self-reactive B cells. It is important to point out that we did not observe $\mathrm{T}$ cell-mediated immune responses directed toward $\mathrm{mDEL}$, indicating that $\mathrm{mDEL}$ is truly perceived as "self" in our model. These observations also suggest mechanisms of tolerance that involve diverse immune cell subsets. Previous studies have shown important functions of tolerogenic subsets of dendritic cells and T regulatory cells in actively controlling immune responses to self- and commensal-antigens in gut $(43,44)$. It would be interesting to further investigate the possible interplay between tolerogenic immune cell subsets and induction of B cell tolerance in the GALT. Importantly, a B cell-intrinsic breach in tolerance by Bcl2 expression in our model was sufficient to induce an inflammatory phenotype and development of pathologies, indicating that B cells play a prominent role in regulating tolerance to self-antigen(s) in the gut.

We show that ectopic expression of BCL2 rescued the survival of self-reactive B cells. Interestingly, the transcriptomic profiling of BCL2-overexpressing HEL-specific B cells still showed activation of the TGF- $\beta$ signaling pathway, suggesting that B cell-intrinsic survival signal does not alter the upstream events that lead to induction of TGF- $\beta$ signaling in self-reactive B cells. Importantly, our results clearly show that breach in tolerance induction by forced expression of BCL2 in B cells triggered a cascade of events that promotes activation of an inflammatory immune signature. These findings strongly suggest that B cells have important immunoregulatory functions in mucosal tissues. Consistent with our findings, absence of B cells in mice causes alterations in the cytokine milieu of GALT (17), and rituximab (B cell-depleting antibody) treatment in humans has been linked to development of colitis (45). In our studies, breakdown of B cell-intrinsic tolerance mechanisms by BCL2 expression caused development of overt inflammation with many of the 
clinical symptoms commonly associated with diseases such as autoimmune enteropathy and celiac disease in humans. This to our knowledge is the first model to study B cell tolerance to gut-associated self-antigens.

In summary, we generated and used a potentially novel mouse model to interrogate B cell-specific responses to their cognate autoantigen in gut. We performed a systematic analysis to show that B cell responses to an autoantigen are actively curtailed by cell-intrinsic tolerance mechanisms in gut and any breach in this process leads to development of pathologies. We further provide what we believe to be novel insights into the molecular mechanisms that control the induction of peripheral tolerance and identify the TGF- $\beta$ signaling pathway as a critical checkpoint for regulating this process.

\section{Methods}

Mice. Villin ${ }^{\text {cret }} \mathrm{mDEL}^{\text {loxp }} \mathrm{SW}_{\mathrm{HEL}}$ and Villin ${ }^{\text {cret }} \mathrm{mDEL}{ }^{\mathrm{wt}} \mathrm{SW}_{\mathrm{HEL}}$ control mice used in the various experiments were obtained by crossing Villin ${ }^{\text {Cret }}$ (Jackson), mDEL (generated in-house), and SWHEL mice (provided by Robert Brink, Garvan Institute of Medical Research, Darlinghurst, Australia). All mice used were kept on a $\mathrm{C} 57 / \mathrm{B} 6$ background. To generate the $\mathrm{RVillin}^{\text {cre }} \mathrm{mDEL}^{\text {loxp }}$ mice and reconstituted control mice, 8- to 12-week-old Villin ${ }^{\text {cre }} \mathrm{mDEL} \mathrm{L}^{\text {loxp }}$ mice (generated in-house by crossing Villin ${ }^{\text {cret }}$ and $\mathrm{mDEL}^{\text {loxp }}$ mice) were lethally irradiated (10 Gy) and reconstituted via i.v. injection (performed by vivarium staff at Sanford Burnham Prebys Medical Discovery Institute) with approximately $6 \times 10^{6}$ to $8 \times 10^{6}$ bone marrow cells from $\mathrm{SW}_{\mathrm{HEL}}$ or $\mathrm{SW}_{\mathrm{HEL}}$ Rag2 $2^{\mathrm{KO}}$ or $\mathrm{SW}_{\mathrm{HEL}}$ Bcl2 or $\mathrm{SW}_{\mathrm{HEL}}$ Baff mice. The mice were given antibiotics $(5 \mathrm{~mL}$ sulfamethoxazole in autoclaved water) for 4 weeks and regular water for another 4 weeks before use.

Adoptive transfers. For the mice used in the adoptive transfer studies, Villin ${ }^{\text {cret }} \mathrm{mDEL}^{\text {loxp }}$ mice were i.v. injected with $10 \times 10^{6}$ to $15 \times 10^{6}$ anti-CD43-depleted MACS-purified (Miltenyi) splenic B cells from SW-HEL mice. For the TGF- $\beta$ receptor inhibitor studies, before injection cells were either left untreated or treated with DMSO or a TGF- $\beta$ I/II receptor inhibitor for 2 hours and labeled with CTV, CFSE, or eFlour670 (eBioscience). We used LY2109761 (Selleck) at the concentration of $5 \mu \mathrm{M}$ per ml. Mice were sacrificed 1,3 , and 5 days later and analyzed by flow cytometry.

Histology. Spleens and PPs were frozen and stored at $-80^{\circ} \mathrm{C}$ in Tissue-Tek O.C.T. Compound until ready for sectioning. 6- to 8 - $\mu \mathrm{m}$ sections were fixed with acetone for 10 minutes at $4^{\circ} \mathrm{C}$ and washed 3 times with PBS at 5 minutes per wash. Slides were then blocked with PBS plus 5\% FBS for 1 hour at room temperature in a humidity chamber and were subsequently stained with HEL-biotinylated and Bim APC for 2 hours at room temperature. The slides were then washed 3 times with PBS plus $0.5 \%$ Tween and stained with streptavidin Cy3, washed, and mounted with Fluoro-Gel Mounting Medium (Electron Microscopy Sciences). Slides were imaged using a Zeiss Imager M1, and Photoshop was used to overlay and edit images. For H\&E staining, tissues were drop fixed in $10 \%$ zinc formalin. Tissues were embedded in paraffin and stained with $\mathrm{H} \& \mathrm{E}$ at the SBP histology core facility.

BrdU labeling. Mice were given $0.5 \mathrm{mg} / \mathrm{mL}$ BrdU (MilliporeSigma) plus 2\% sucrose in their drinking water for 8 weeks, and B cell turnover was measured by flow cytometry. Cells were harvested from spleens, pLNs, mLNs, and PPs. Cells were stained with surface antibodies (see below), fixed, and then stained, following the manufacturer's instruction.

Flow cytometry staining. Spleens, pLNs, mLNs, and PPs were isolated from mice euthanized with $\mathrm{CO}^{2}$. Organs were put into $10 \% \mathrm{FBS}$ in PBS. $1 \times 10^{6}$ to $2 \times 10^{6}$ cells were stained with $0.2-0.5 \mu \mathrm{g}$ antibody in FACS buffer for 25 minutes and were subsequently stained with secondary antibody when necessary. AntiB220 (RA3-6B2), -CD86 (B7-2), -IgM(11/41), -CD69(H1.2F3), -CD95/Fas (J02), and -GL7 conjugated to APC, APC780, PE, FITC, PeCy7, or PerCp Cy5.5 were used (antibodies were from eBioscience). To stain for HEL-binding B cells, HEL bio (GeneTex) was used and revealed by using streptavidin-PerCpCy5.5, PECy7 or PE. Alternatively, cells were incubated with soluble HEL, followed by anti-HEL biotinylated or anti-HEL (Rockland) and subsequently stained with either streptavidin or donkey anti-Rabbit FITC (Jackson), respectively. Anti-SMAD2 pS465/pS467 (clone 072-670) was purchased from BD Biosciences, and PE-conjugated mouse anti-TGF $\beta$ R1 was purchased from R\&D Systems. Live cells were identified using forward and side scatter. Data were acquired with a BD FACSCanto using the FACS DIVA software (BD Biosciences), and data were analyzed using FlowJo (Treestar).

Anti-HEL flow assay. To detect HEL-specific antibodies in serum and fecal extracts, we modified the sheep red blood cells (SRBCs) assay developed in our laboratory (25). Fecal extracts were dissolved in a 1:1 ratio of PBS with protease inhibitor. HEL was conjugated to SRBC (46). Standard SRBC assay was then followed with HEL-conjugated SRBCs to detect HEL-specific anti-IgM, anti-IgG2, anti-IgG1, and anti-IgA antibodies (25). 
Data analysis. All flow cytometry data were collected with BD FACSDiva and analyzed using FlowJo Version 8.8.7.

Intestinal epithelial cell isolation. The intestine was removed and transferred into cold PBS. Intestinal contents were removed, and the intestine was cut open longitudinally and washed in cold PBS. The tissue was then placed into a tube containing prewarmed PBS and $1 \mathrm{mM} \mathrm{DTT}$ and shaken for 10 minutes at $0.006158 \mathrm{~g}$ and $37^{\circ} \mathrm{C}$ and then washed with PBS. The tissue was removed and incubated in HBSS supplemented with 1.5 $\mathrm{mM}$ EDTA for 15 minutes at $0.006158 \mathrm{~g}$ and $37^{\circ} \mathrm{C}$. Tubes containing the tissue were vortexed for 1 minute, and tissue was removed. Intestinal epithelial cells were centrifuged down to a pellet and resuspended in $1 \mathrm{~mL}$ PBS. Cells were then filtered and either stained for flow cytometry or used for the lysozyme activity assay.

Transfection of HEK293T cells. HEK293T cells were transfected with either an empty MSCV-P2GM plasmid or MSCV-P2GM mDEL plasmid. $3 \mu \mathrm{g}$ plasmid was added to $18 \mu \mathrm{PEI}$ and $172 \mu \mathrm{DMEM}$ and mixed gently. Plasmid was incubated at room temperature for 20 minutes before the addition of $2 \mathrm{~mL}$ complete DMEM (10\% FBS, $2 \mathrm{mM}$ L-glutamine, $100 \mathrm{U} / \mathrm{mL}$ penicillin, and $100 \mu \mathrm{g} / \mathrm{mL}$ streptomycin). HE293T cells were incubated in plasmid for 2 days. Additional complete DMEM was added after overnight incubation, and whole media were changed 2 days after transfection. Cells were analyzed by flow cytometry on the third day to check transfection efficiency.

Lysozyme activity assay. To analyze lysozyme activity, the EnzChek Lysozyme Assay Kit (Molecular Probes) was used according to manufacturer's instructions, with modifications for testing on cells. Transfected HEK293T cells, isolated IECs, and whole intestine sections were used for the assay. $5 \times 10^{4}$ $\mathrm{mDEL}$-expressing cells or 8-mm sections of the small intestine of Villin ${ }^{\text {cret }} \mathrm{mDEL}^{\text {loxp }}$ mice were used. Fluorescence was measured using a fluorescence microplate reader with a fluorescein filter.

gDNA extraction. gDNA was extracted from fecal pellets collected from mice using a Qiagen QIAamp Fast DNA Stool Mini Kit according to manufacturer's instructions with adjustments. Stool was collected into 2-mL microcentrifuge tubes (Eppendorf). $1 \mathrm{~mL}$ InhibitEX buffer was added to each stool sample and vortexed until stool sample was homogenized. The suspension was heated to $95^{\circ} \mathrm{C}$ for $10-15$ minutes and vortexed for 15 seconds. The sample was centrifuged for 1 minute, and $600 \mu 1$ supernatant was added to $25 \mu 1$ Proteinase K (Roche). $600 \mu 1$ Buffer AL was added to the sample and vortexed for 15 seconds before it was incubated at $70^{\circ} \mathrm{C}$ for 10 minutes. $600 \mu$ ethanol was added to the lysate and mixed by vortexing. Lysate was added to the QIAamp spin column and centrifuged for 1 minute. Filtrate was discarded. Once all sample has been loaded onto column, $500 \mu$ buffer AW1 (Qiagen QIAamp Fast DNA Stool Mini Kit) was added to the column and centrifuged for 1 minute. The column was then washed with $500 \mu 1$ buffer AW2 (Qiagen QIAamp Fast DNA Stool Mini Kit) and centrifuged for 3 minutes. Column was centrifuged for 3 minutes and allowed to dry for 5 minutes at room temperature. To elute gDNA, $200 \mu 1$ buffer ATE (Qiagen QIAamp Fast DNA Stool Mini Kit) was added to the column membrane and incubated for 2 minutes at room temperature before elution by centrifugation for 1 minute. Samples were stored at $-20^{\circ} \mathrm{C}$.

$R N A$ sequencing. HEL-specific cells and non-HEL-specific cells were FAC sorted in TRIzol Reagent (Invitrogen) from spleens, $\mathrm{mLNs}$, and PPs of Villin ${ }^{\text {cre+ }} \mathrm{mDEL}^{\text {loxp }} \mathrm{SW}_{\mathrm{HEL}}$ and RVillin ${ }^{\text {cret }} \mathrm{mDELloxp}(\mathrm{BCL} 2)$ mice $(100,000$ cells in $500 \mu 1$ TRIzol). RNA was isolated by the manufacturer's instruction. Purified RNA was further passed through the Qiagen RNA isolation kit column to remove any remaining residual. cDNA was synthesize using SMART (Switching Mechanism at 5' End of RNA template) technology, and RNA sequencing was performed at genomics core of La Jolla Institute of Allergy and Immunology, La Jolla, California, USA. The data discussed in this publication have been deposited in NCBI's Gene Expression Omnibus (accession GSE133159).

Statistics. All the graphs were generated using ELISA data. Flow and RT-PCR data were analyzed with Microsoft Office Excel and Prism 6. All the statistical analysis were done by unpaired 1-tailed Student's $t$ test or 2-way ANOVA for analyzing multiple groups. All the experiments were performed at least 3 times, unless specified otherwise in the figure legends.

Study approval. All animals were treated in accordance with the ethical standards set approved by Sanford Burnham Prebys Medical Discovery's Institutional Animal Care and Use Committee.

\section{Author contributions}

AS, CC, and RCR designed the experiments; AS, CC, JJ, CRL, EK, NB, and JRA conducted the experiments; AS, CC, JJ, and WWL analyzed the experiments; AS wrote the manuscript; CRL and EK helped in preparing the manuscript; and JRA and RCR supervised the study. 


\section{Acknowledgments}

We are thankful to David Nemazee at The Scripps Research Institute for providing the BAFF-transgenic mice. We acknowledge Buddy Charbono from SBP vivarium for performing all the injections and Alfredo Chavez, Andy Vasquez, and Diana Sandoval for maintaining all mouse colonies. We are grateful to all the Rickert lab members for providing feedback and suggestions during manuscript preparation. This research is supported by NIH grant R01 AI122344 (to JRA). AS is a fellow of the Leukemia and Lymphoma Society.

Address correspondence to: Ashima Shukla, Tumor Microenvironment and Cancer Immunology Program, Sanford Burnham Prebys Medical Discovery Institute, 10901 N. Torrey Pines Road, La Jolla, California 92037, USA. Phone: 858.646.3100 ext. 3487; Email: ashukla@sbpdiscovery.org.

1. Eckburg PB, et al. Diversity of the human intestinal microbial flora. Science. 2005;308(5728):1635-1638.

2. Macdonald TT, Monteleone G. Immunity, inflammation, and allergy in the gut. Science. 2005;307(5717):1920-1925

3. Fasano A. Leaky gut and autoimmune diseases. Clin Rev Allergy Immunol. 2012;42(1):71-78.

4. Macpherson AJ, Uhr T. Induction of protective IgA by intestinal dendritic cells carrying commensal bacteria. Science. 2004;303(5664):1662-1665.

5. Artis D. Epithelial-cell recognition of commensal bacteria and maintenance of immune homeostasis in the gut. Nat Rev Immunol. 2008;8(6):411-420.

6. Fubara ES, Freter R. Protection against enteric bacterial infection by secretory IgA antibodies. J Immunol. 1973;111(2):395-403

7. Gutzeit C, Magri G, Cerutti A. Intestinal IgA production and its role in host-microbe interaction. Immunol Rev. 2014;260(1):76-85

8. Suzuki K, et al. Aberrant expansion of segmented filamentous bacteria in IgA-deficient gut. Proc Natl Acad Sci USA. 2004;101(7):1981-1986.

9. Brown EM, Sadarangani M, Finlay BB. The role of the immune system in governing host-microbe interactions in the intestine. Nat Immunol. 2013;14(7):660-667.

10. Round JL, Mazmanian SK. The gut microbiota shapes intestinal immune responses during health and disease. Nat Rev Immunol. 2009;9(5):313-323.

11. Mora JR, et al. Generation of gut-homing IgA-secreting B cells by intestinal dendritic cells. Science. 2006;314(5802):1157-1160.

12. Mizoguchi A, Mizoguchi E, Takedatsu H, Blumberg RS, Bhan AK. Chronic intestinal inflammatory condition generates IL-10-producing regulatory B cell subset characterized by CD1d upregulation. Immunity. 2002;16(2):219-230.

13. Song F, et al. The Peyer's patch is a critical immunoregulatory site for mucosal tolerance in experimental autoimmune encephalomylelitis (EAE). J Autoimmun. 2008;30(4):230-237.

14. Uematsu S, et al. Regulation of humoral and cellular gut immunity by lamina propria dendritic cells expressing Toll-like receptor 5. Nat Immunol. 2008;9(7):769-776.

15. Rosser EC, et al. Regulatory B cells are induced by gut microbiota-driven interleukin-1 $\beta$ and interleukin- 6 production. Nat Med. 2014;20(11):1334-1339.

16. Sattler S, et al. IL-10-producing regulatory B cells induced by IL-33 (Breg(IL-33)) effectively attenuate mucosal inflammatory responses in the gut. J Autoimmun. 2014;50:107-122.

17. Gonnella PA, Waldner HP, Weiner HL. B cell-deficient (mu MT) mice have alterations in the cytokine microenvironment of the gut-associated lymphoid tissue (GALT) and a defect in the low dose mechanism of oral tolerance. J Immunol. 2001;166(7):4456-4464.

18. Nemazee D. Mechanisms of central tolerance for B cells. Nat Rev Immunol. 2017;17(5):281-294.

19. Cambier JC, Gauld SB, Merrell KT, Vilen BJ. B-cell anergy: from transgenic models to naturally occurring anergic B cells? Nat Rev Immunol. 2007;7(8):633-643

20. Yau IW, Cato MH, Jellusova J, Hurtado de Mendoza T, Brink R, Rickert RC. Censoring of self-reactive B cells by follicular dendritic cell-displayed self-antigen. J Immunol. 2013;191(3):1082-1090

21. Wesemann DR, et al. Microbial colonization influences early B-lineage development in the gut lamina propria. Nature. 2013;501(7465):112-115.

22. Adams CL, Macleod MK, James Milner-White E, Aitken R, Garside P, Stott DI. Complete analysis of the B-cell response to a protein antigen, from in vivo germinal centre formation to 3-D modelling of affinity maturation. Immunology. 2003;108(3):274-287.

23. Fischer MB, et al. Dependence of germinal center B cells on expression of CD21/CD35 for survival. Science. 1998;280(5363):582-585.

24. Phan TG, et al. B cell receptor-independent stimuli trigger immunoglobulin (Ig) class switch recombination and production of IgG autoantibodies by anergic self-reactive B cells. J Exp Med. 2003;197(7):845-860.

25. McAllister EJ, Apgar JR, Leung CR, Rickert RC, Jellusova J. New methods to analyze B cell immune responses to thymus-dependent antigen sheep red blood cells. J Immunol. 2017;199(8):2998-3003.

26. Gavin AL, et al. deltaBAFF, a splice isoform of BAFF, opposes full-length BAFF activity in vivo in transgenic mouse models. J Immunol. 2005;175(1):319-328.

27. Thien M, et al. Excess BAFF rescues self-reactive B cells from peripheral deletion and allows them to enter forbidden follicular and marginal zone niches. Immunity. 2004;20(6):785-798.

28. Fu Y, et al. Comparison of non-invasive biomarkers faecal BAFF, calprotectin and FOBT in discriminating IBS from IBD and evaluation of intestinal inflammation. Sci Rep. 2017;7(1):2669.

29. Vaux DL, Cory S, Adams JM. Bcl-2 gene promotes haemopoietic cell survival and cooperates with c-myc to immortalize pre-B cells. Nature. 1988;335(6189):440-442.

30. McDonnell TJ, et al. bcl-2-immunoglobulin transgenic mice demonstrate extended B cell survival and follicular lymphoproliferation. 
Cell. 1989;57(1):79-88.

31. Puthalakath H, Huang DC, O'Reilly LA, King SM, Strasser A. The proapoptotic activity of the Bcl-2 family member Bim is regulated by interaction with the dynein motor complex. Mol Cell. 1999;3(3):287-296.

32. Wöbke TK, von Knethen A, Steinhilber D, Sorg BL. CD69 is a TGF- $\beta / 1 \alpha, 25$-dihydroxyvitamin D3 target gene in monocytes. PLoS One. 2013;8(5):e64635.

33. Gros MJ, Naquet P, Guinamard RR. Cell intrinsic TGF-beta 1 regulation of B cells. J Immunol. 2008;180(12):8153-8158.

34. Cazac BB, Roes J. TGF-beta receptor controls B cell responsiveness and induction of IgA in vivo. Immunity. 2000;13(4):443-451.

35. Bjarnadóttir $\mathrm{K}$, et al. B cell-derived transforming growth factor- $\beta 1$ expression limits the induction phase of autoimmune neuroinflammation. Sci Rep. 2016;6:34594.

36. Snapper CM, Waegell W, Beernink H, Dasch JR. Transforming growth factor-beta 1 is required for secretion of IgG of all subclasses by LPS-activated murine B cells in vitro. J Immunol. 1993;151(9):4625-4636.

37. Zan H, Cerutti A, Dramitinos P, Schaffer A, Casali P. CD40 engagement triggers switching to IgA1 and IgA2 in human B cells through induction of endogenous TGF-beta: evidence for TGF-beta but not IL-10-dependent direct $\mathrm{S}$ mu $\rightarrow \mathrm{S}$ alpha and sequential S mu $\rightarrow$ S gamma, S gamma $\rightarrow$ S alpha DNA recombination. J Immunol. 1998;161(10):5217-5225.

38. Lebman DA, Edmiston JS. The role of TGF-beta in growth, differentiation, and maturation of B lymphocytes. Microbes Infect. 1999;1(15):1297-1304.

39. Spender LC, et al. TGF-beta induces apoptosis in human B cells by transcriptional regulation of BIK and BCL-XL. Cell Death Differ. 2009;16(4):593-602.

40. Wildey GM, Patil S, Howe PH. Smad3 potentiates transforming growth factor beta (TGFbeta )-induced apoptosis and expression of the BH3-only protein Bim in WEHI 231 B lymphocytes. J Biol Chem. 2003;278(20):18069-18077.

41. Wallace $\mathrm{CH}$, et al. B lymphocytes confer immune tolerance via cell surface GARP-TGF- $\beta$ complex. JCI Insight. 2018;3(7):99863.

42. Dedobbeleer O, Stockis J, van der Woning B, Coulie PG, Lucas S. Cutting Edge: Active TGF- $\beta 1$ released from GARP/TGF$\beta 1$ complexes on the surface of stimulated human B lymphocytes increases class-switch recombination and production of IgA. J Immunol. 2017;199(2):391-396.

43. Hadis $\mathrm{U}$, et al. Intestinal tolerance requires gut homing and expansion of FoxP3+ regulatory $\mathrm{T}$ cells in the lamina propria Immunity. 2011;34(2):237-246.

44. Manicassamy S, et al. Activation of beta-catenin in dendritic cells regulates immunity versus tolerance in the intestine. Science. 2010;329(5993):849-853.

45. Eckmann JD, et al. P100 RITUXIMAB-INDUCED COLITIS: THE MAYO CLINIC EXPERIENCE. Gastroenterology. 2018;154(1):S51.

46. Paus D, Phan TG, Chan TD, Gardam S, Basten A, Brink R. Antigen recognition strength regulates the choice between extrafollicular plasma cell and germinal center B cell differentiation. J Exp Med. 2006;203(4):1081-1091. 